\title{
Effectiveness of acceptance and commitment group therapy on marital distress, marital conflict and optimism in married women visited the counseling center of Imam Khomeini Relief Foundation in Kermanshah
}

\author{
Ahmad Amani ${ }^{1}$, Omid Isanejad ${ }^{2}$, Elahe Alipour ${ }^{3 *}$ \\ 1. Associate. Prof, Department of Counseling, University of Kurdistan, Sanandaj, Iran. \\ 2. Assist. Prof, Department of Counseling, University of Kurdistan, Sanandaj, Iran. \\ 3. Master of Family Counseling. Department of Counseling, University of Kurdistan, Sanandaj, Iran. \\ (Corresponding Author)
}

\begin{abstract}
Aim: The study aimed at determining the effectiveness of acceptance and commitment group therapy on marital distress, marital conflict, and optimism.

Methodology: The study was formed of quasi-experimental design with pretest-posttest and follow-up. 24 married women with marital problems who visited the counseling center of Imam Khomeini Relief Foundation were selected and randomized into control and experimental groups based on group counseling standards ( $\mathrm{n}=12$ for each group). Research tools were Marital Satisfaction Inventory-Revised (MSI-R), Marital Conflict QuestionnaireRevised (R-MCQ), and Life Orientation Test- Revised (LOT-R). The experimental group participated in ten ACT group sessions. After the ending a posttest was carried out in both groups. Multivariate analysis of covariance (MANCOVA) was performed to analyze the data. Findings: The results of the study showed that acceptance and commitment group therap At the post-test and follow-up stage cause reduces marital distress and marital conflict and increases the optimism. so acceptance and commitment group therapy is effective on marital distress $(\mathrm{P}<0.05)$, marital conflict $(\mathrm{P}<0.05)$, and optimism $(\mathrm{P}<0.05)$.

Conclusion: The results emphasize the importance of the use of ACT group therapy in counseling centers and family education classes to solve marital problems in couples.

Keywords: Acceptance and commitment group therapy, marital distress, marital conflict, optimism
\end{abstract}




\title{
بررسى اثربخشى در مان مبتنى بر يذيرش و تعهد به شيوهى كروهى بر آشفتكى زناشويى، تعارض زناشويى و خوشبينى در زنان متأهل مراجعه كننده به مركز مشاوره كميته امداد شهر كرمانشاه
}

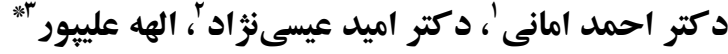

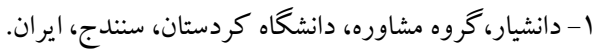 \\ Ahmad_counsellor@yahoo.com \\ r-rاستاديار، گروه مشاوره، دانشكاه كردستان، سندج، ايران. \\ farhangmad@gmail.com \\ ب- كارشناس ارشد، كروه مشاوره، دانشخاه كردستان، سندج، ايران. (مولف مسئول). \\ elahealipour20@gmail.Com
}

جكکטه

هدف: هدف بثزوهش تعيين اثربخشى درمان مبتى بر بذيرش و تعهل بهشيوهى گروهى بر آشفتكىزناشويى، تعارضزناشويى و خوشينى بود.

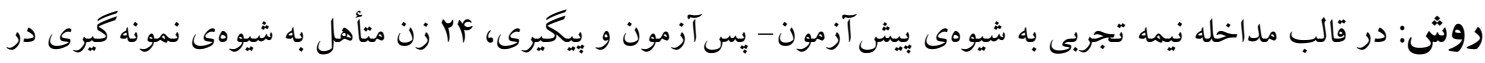

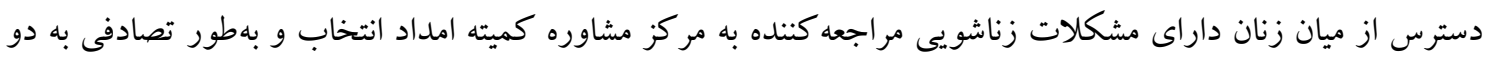

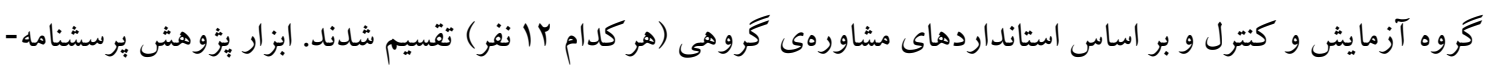

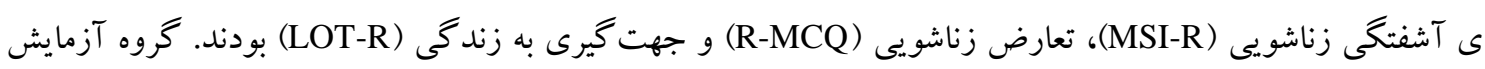

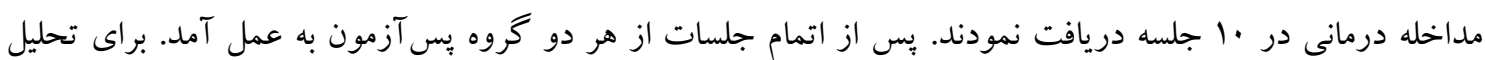
دادهها از تحليل كوواريانس جندمتغيره استفاده شد.

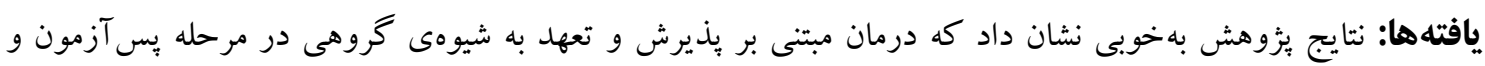

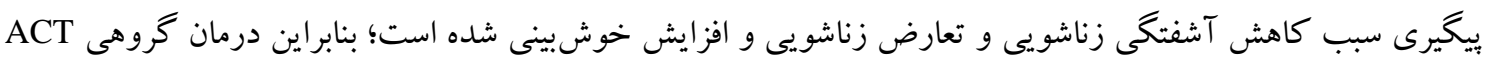

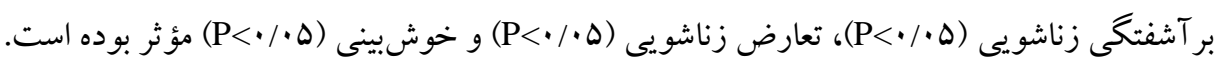
نتيجه كيرى: نتايج بر اهميت كاربرد اين درمان در مراكز مشاوره و كلاسهاى آموزش خانواده جهت حل مشكلات زناشويى زوجها تأكيد دارد...

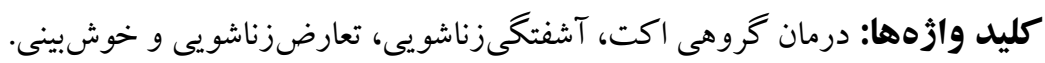


تعيين كنندهاى مهم ساز كارى هستند. خوشبينى انتظار

كلى وقوع امور خوشايند و مطلوب فراوان و امور

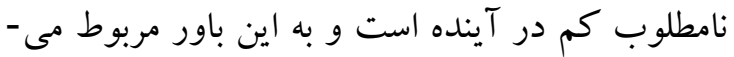

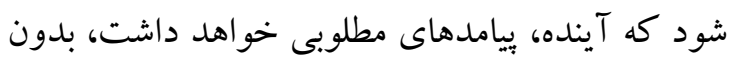
اينكه توانايى فرد براى كنترل و مواجهه با اين بيامدها

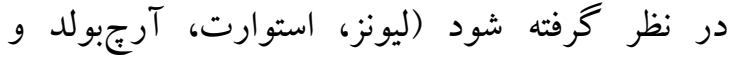

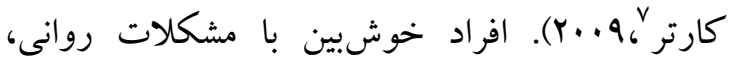
بزشكى و فيزيكى بهتر از افرادى كه سطح بايينى از خوشينى دارند روبهرو مىشوند. در تجربه كار با بيماران مبتلا به صرع ثابت شده است كه افراد خوشبين به منظور كاهش خطرات بيمارى با مسائل مهم در زمينه

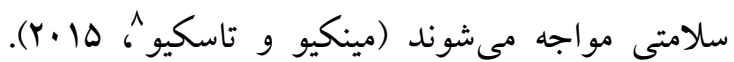
همجنين شواهد حاكى از اين است كه افراد خوشبين

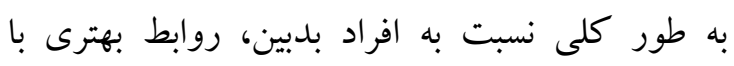

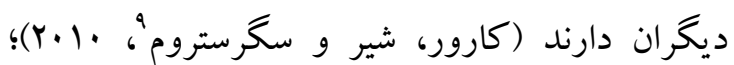
روى هم رفته در حال حاضر محققان خوشينى را بهنوان يكك منبع مفيد در روابط بين فردى مىدانند

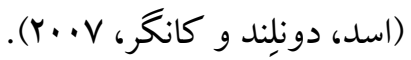
هم درمانكران و هم زوجها عقيده دارند كه شايع - هون ترين و مخربترين مشكلات در ازدواجهاى شكست خورده مشكلات ارتباطى است (روبرتس "، مردين (Y... ناخشنودى و تعارضات زناشويى است (كلاسر") 1991). عدم توافق در هر رابطه زناشويى طبيعى است

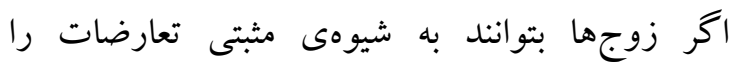
مديريت كنند و توانيى حل آن را داشته باشند، وجود

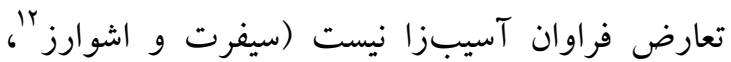
1). (Y.1). رابطه تعارض و رضايت زناشويى از بيشينه يُزوهشى جِندين سالهاى برخوردار است (كمبِداش و

7. Lyons, Stewart, Archbold, \& Carter

8 .Mincu \& Taşcu

9.Carver, Scheier, \& Segerstrom

10 .Roberts

11. Glasser

12. Siffert \& Schwarz
خانواده جوهرهاى زنده و در حال تغيير است كه با استفاده از اعضاى خويش و در جريان ارتباطى دائمى، تعاملى و طرح دار با يكديخر يك كل را سازماندهى مى كند و در طول زمان و مكان گسترش مى ويابد (موسوى، رشيدى و كلمحمديان، هوبا). خانواده از لحاظ قدمت، ابتدايىترين و به لحاظ كستردگى، جهان شمولترين نهاد اجتماعى است، اين امر نشان مىدهد كه تشكيل خانواده يكى از اساسىترين و طبيعىترين نيازهاى انسان محسوب مىشود (يارسه، نادرى و

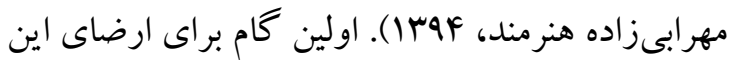
نياز اساسى و طبيعى ازدواج است. بهرغم خوشايند بودن بيوند ازدواج، رضايت زوجين به آسانى به دست نمى آيد و درنتيجه قوى ترين بيوند انسانى يعنى ازدواج،

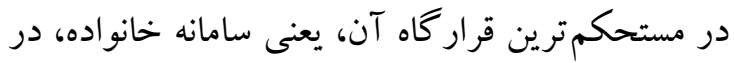

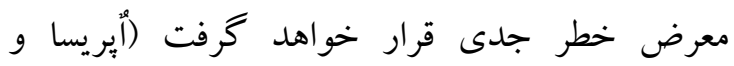

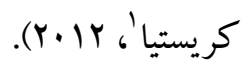
ادبيات زناشويى به طور گسترده، عوامل مؤثر در بيش بردن رفتارهاى ارتباطى را مطالعه مى كند (هامت،

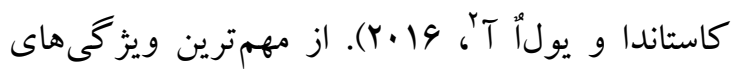
زوجين متعادل، توانايى برخورد با جهان وبيرامون

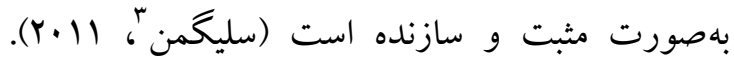
مطالعه بر روى خوشبينى را به عنوان يكك سازه روان-

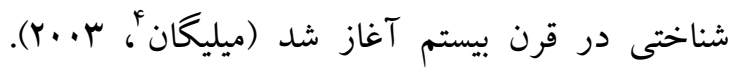
خوشبينى يكك حالت عاطفى مثبت است كه باعث مىشود شخص در برابر اختلالات روانى با (اميد و

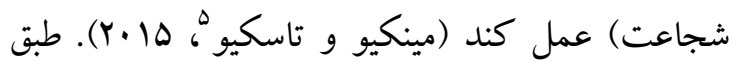

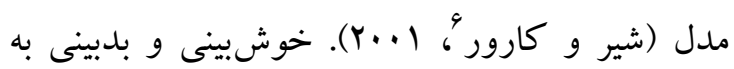
ترتيب بهعنوان انتظار نتايج فراكير مثبت و منفى

1. Oprisan \& Cristea

2. Hammett, Castañeda, \& Ulloa

3. Seligman

4. Milligan

5. Mincu \& Taşcu

6. Scheier \& Carver 
سيستمى خانواده، زوجين و سيستم والد- فرزندى يشينى كننده مهم احساسات كود كان در بزرگكسالى هستند براى مثال: تعارضات زناشويى مىتواند باعث افزايش تنش، تعاملات والد- فرزندى منفى و افزايش ابتلا به دلبستگى ناايمن در كودكان شود (فرانكل،

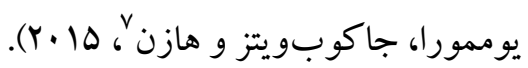
همبستكى مثبت بين تعارضزناشويى با افسردگى خانو اده و مشكلات شغلى از بيامدهاى روانى حاصل از اختلال و آشفتگىزناشويى در ازدواج است (كويى و و همكاران، سو1999). به اعتقاد ويسمن، شلدون و و گورينگ' (Y.... (Y) بسيارى از اختلافات تحت تأثير آشفتگىزناشويى به وجود مى آيند و شيوع آن، هم در مطالعات شيوعشناسى اجتماعى و هم در يزوهشهاى بالينى نشان داده شده است (كريدر و جيسون'،

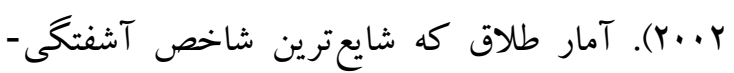
زناشويى است نشانكر آن است كه رضايت زناشويى به آسانى قابل دستيابى نيست و زوجهاى فراوانى درجات متفاوتى از آشفتگى و عدم رضايت را تجربه مى كنند

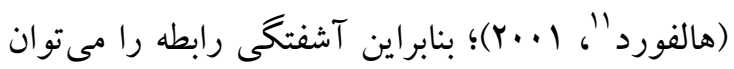
به صورت عملياتى و تحت عنوان احساس نارضايتى حداقل يكى از زوجين از رابطه زناشويى تعريف كرد

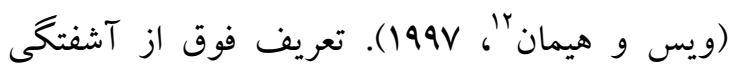
رابطه، مستلزم اين است كه تنها يكى از زوجين احساس نارضايتى كند، نارضايتى بهشدت از يكك زوج به

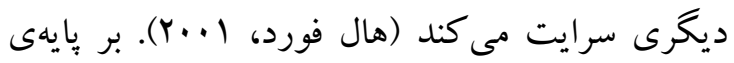
كزارش انستيتوى ملى سلامت روان آمريكا، اختلال و آشفتكى در ازدواج عامل بسيارى از مشكلات روانى بيماران بسترى در بخش روانى بيمارستانهاى آمريكا است (حسينيان و همكاران، IMNV). بسيارى از روان-

7. Frankel, Umemura, Jacobvitz, \& Hazen

8. Coie

9. Whisman, Sheldon, \& Goering

10. Kreider \& Jason

11. Halford

12. Weiss \& Heyman
تايلر '، Y 1Y). تعارضاتزناشويى يكى از مشكلات رايج زوجها در دنياى امروز است (سيرز، كوهن،

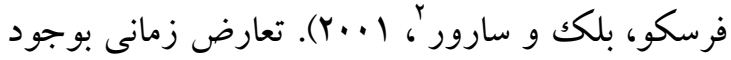
مى آيد كه زوجها به دليل همكارى و تصميمات مشتركى كه مى گيرند، درجات مختلفى از استقلال و و همبستكى را نشان مىدهند. اين تفاوتها را مى مئوان روى يك ييوستار از تعارض خفيف تا تعارض كامل

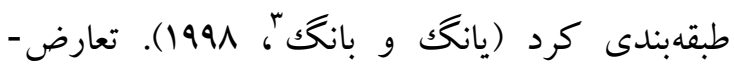
زناشويى ناشى از ناهماهنكى زن و شوهر در نوع نيازها و روشهاى ارضاى آن، خودمحورى، اختلاف در خواستهها، طرحوارههاى رفتارى و رفتار غيرمسئولانه نسبت به ارتباط زناشويى و ازدواج است (كلاسهُ

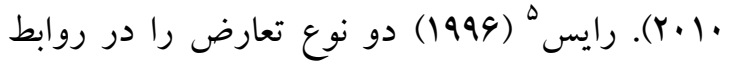
زناشويى مطرح مىسازد: تعارض سازنده و تعارض مخرب. در تعارض سازنده تمر كز بر حل مسئله بوده و

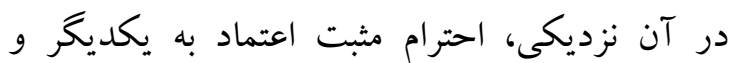
هيجان منفى و ياسخ كلامى اندكى بين زوجين وجود

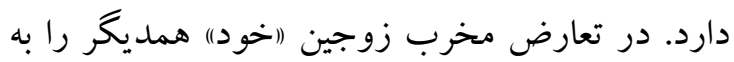
جاى مسئله موردحمله قرار مىدهند. در اين تعارض از طريق سرزنش و انتقاد، هريكك سعى دارند ديخرى را تحت نفوذ خود در آورده و اظهارنظرهاى بسيار منفى نري عليه يكديگر به كار مىبرند كه در اين حالت ارتباط درستى بين آنها برقرار نمىشود. در اين نوع ارتباط بحث و مجادلههاى بيهوده و مخرب، بى اعتمادى، بى احترامى، توهين، خصومت، دشمنى و دشنام مشاهده

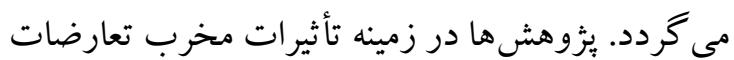
زناشويى نشان مىدهد كه تعارضات زناشويى تأثيرات زيانآورى بر سلامت، جسم، روان و خانواده دارد

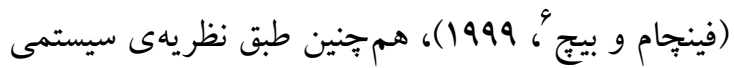

1. Kamp Dush \& Taylor

2. Sayers, Kohn, Fresco, Bellack, \& Sarwer

3. Young \& Long

4. Glasser

5 .Rice

6. Fincham \& Beach 
در ادبيات موج اول و دوم رفتاردرمانى و بهبود درمان شناختى- رفتارى كلاسيك، آن هم براى تبيين آثار آشكار زبان و شناخت انسان لزوم بهوجود آمدن موج سوم درمانشناختى رفتارى را نشان مىدهد (هيز، (Y.19). نمونهاى از سومين موج مداخلات درمان شناختى رفتارى عبارتاند از: درمان مبتنى بر بذيرش و

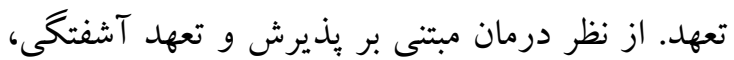
تعارض و فاصلهى عاطفى در زوجها ناشى از تركيب كنترلهاى محكم و بىفايدهى هريك از آنها و و راهبردهاى اجتناب تجربى در رابطه زن و شوهر است و واقعى در نظر گرفتن افكار ارزيابانه منفى و عمل بر طبق آنها جرخه روابط منفى زوجها را حفظ مى كند

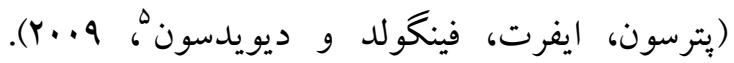

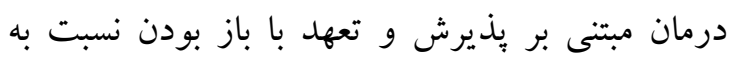

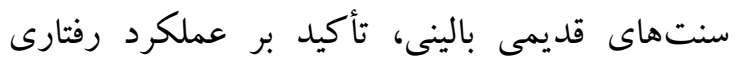
مراجع نه علت يابى و انعطافيذيرى روانشناختى نشان مىدهد كه جرا هم جوشى شناختى و اجتناب تجربى لـ

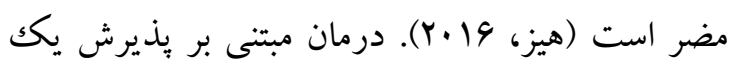
نوع رفتاردرمانى است كه هدف آن به عمل درآوردن اجتناب تجربى و تلاش براى كنترل تجربههاى

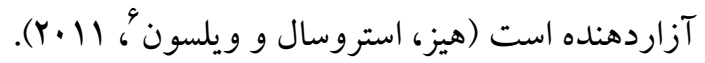

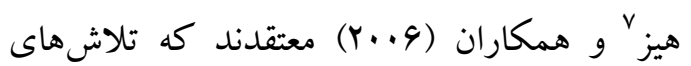
ناموفق ما براى غلبه يافتن يا جلو گيرى از درد و رنج

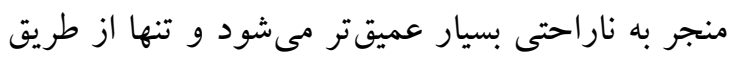

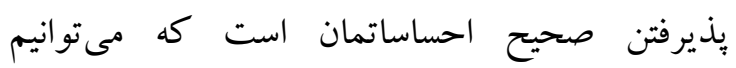
زندكى مان را نجات دهيم و نبايد با تلاش مداوم براى بحتح تبديل كردن روابطمان به جيزهايى كه نيستند، اوضاع را

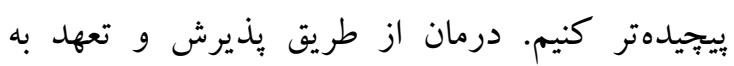

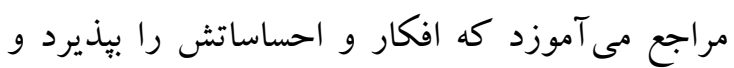
راههاى تازهاى براى زندگى هـى اش انتخاب كند و اقدام

5. Peterson, Eifert, Feingold, \& Davidson 6. Hayes, Strosahl, \& Wilson

7 .Hayes
شناسان و خانواده درمانگران، مهمترين عامل موفق يا ناموفق بودن ازدواج را ويزگ هاى شخصيتى زوجها، جُخونگى تجربهى كودكى و كيفيت روابط بين اعضاى خانواده اصلى مىداند (واناِِ، فوتريس، وانِاٍِ و و

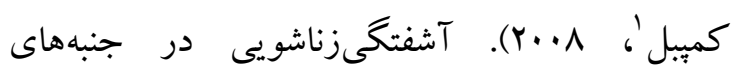
متعددى از روابط زناشويى، هميجون ارتباط عاطفى،

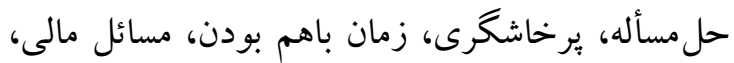
مسائل جنسى، جهت گيرى نقش، رضايت از فرزند و تربيت فرزند اختلال ايجاد مى كند و بسيارى از كود كان ممكن است با مشاهدهى تعارضهاى مزمن ورى و

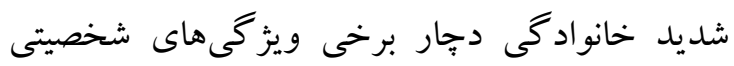
شوند كه بيشبينى كنندهى كيفيت نامطلوب ارتباطهاى

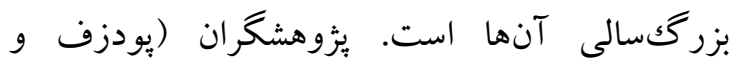

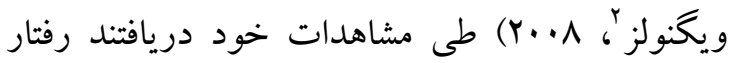
آيندهى فرزندان در زندگى خلى خانوادگى مانند رفتار بيدر و مادرشان خواهد بود و فرض انتقال بين نسلى نيز بيانكنندهى اين احتمال است كه نابسامانىهاى خانوادگى در نسل بعد را آسان كند (ساباتلى، بارتل - بـابل

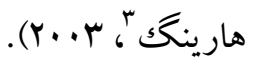

در طول جند دهاى كذشته درمان زوجهاى آشفته و متعارض در بين محققان و درمانگران توجه قابل ملاحظهاى كسب كرده است. اگرجه اثربخشى زوجدرمانى سنتى ثابت شده است، اما نغرانى در مورد محدوديت هاى آن و حفظ تغييرات بلندمدت باعث شد كه بنيان گذاران زوجدرمانى سنتى يكك رويكرد جديد

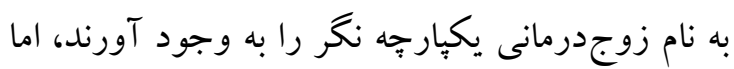
به طور كلى هنوز هم نخرانىهايى در مورد اثرات

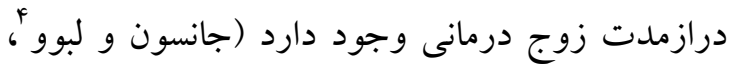
(Y....

1.Van Epp, Futris, Van Epp, \& Campbell 2. Powdthavee \& Vignoles

3 .Sabatelli \& Bartle-Haring

4. Johnson \& Lebow 
مىبخشد و صميميت بين فردى را افزايش مىدهد داده شود و نزديكك شدن به افكار و احساسات مرتبط با اجتناب قبلى و عمل در جهت ساز كار با ارزشهاى رابطهى دو طرفه، اين فرصت را براى زوجها فراهم مى كند تا ارتباط قوىترى برقرار كنند (يترسون و

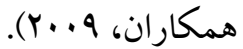
ACT يُوهشهاى زيادى در مورد كاربرد درمان

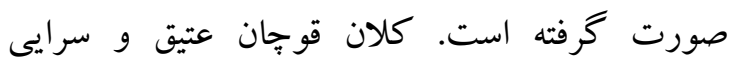

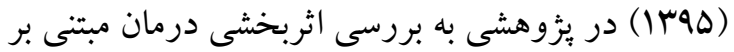
بيرش و تعهل بر ساز گارى زناشويى، رضايت جنسى و

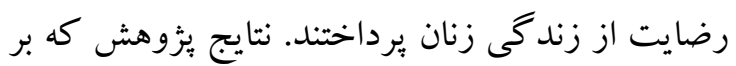

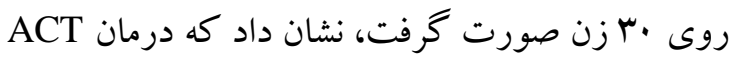

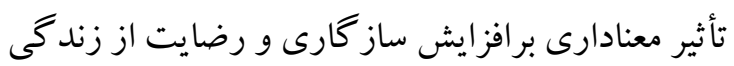
زنان داشته است. كاوسيان، حريفى و كريمى (هوسا) در يزوهشى با هدف بررسى اثربخشى درمان مبتى بر بذيرش و تعهل بر رضايت زناشويى زوجها كه شامل كروه آزمايش و گُواه بود به اين نتيجه رسيدند كه بين

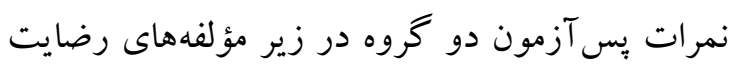
زناشويى، حل تعارض، كنترل و تحريف آرمانى تفاوت معنادار وجود دارد. همجنين عظيمىفر، فاتحىزاده، بهرامى، احمدى و عابدى (هوبr) يُزوهشى با عنوان مقايسه اثربخشى زوجدرمانى شناختى -رفتارى و درمان مبتنى بر بذيرش و تعهل بر افزايش شادى زناشويى زوجين ناراضى انجام دادند. بنا بر تفاوت معنىدار ميان موقعيت مداخله و خط بايه در نمودار دادهها، يافتههاى يثزوهش آنها نشان داد كه مداخلات زوجدرمانى شناختى-رفتارى و درمان مبتنى بر يذيرش و تعهد موجب افزايش شادى زناشويى زوجين شدهاند. بهعلاوه

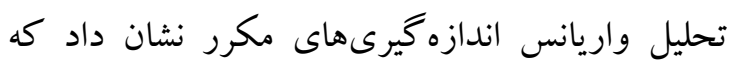
ميان تأثير اين دو رويكر بر افزايش شادى زناشويى التيى

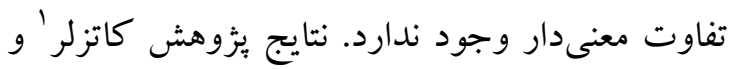

متعهدانه انجام دهد. شش فرايند اصلى در قالب يكك فر آيند زيربنايى (انعطاف يذيرى روانشناختى) به عنوان اجزاى اصلى فرايند تغيير (ACT) معرفىشده است كه

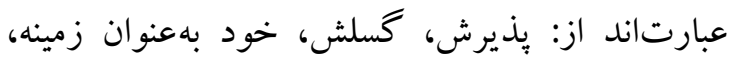
ارتباط با زمان حال، ارزشها، عمل متعهدانه. درمان مبتنى بر يذيرش و تعهد به دنبال كاهش رنجهاى غيرضرورى زوجها كه ناشى از اجتناب تجربى هر يكك از آنهاست، است. هدف اصلى درمان اكت كمكك به

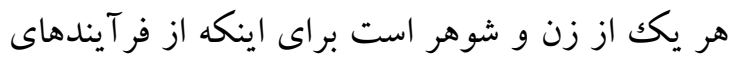
شناختى و واكنش عاطفى خود جه به تنهايى جه در

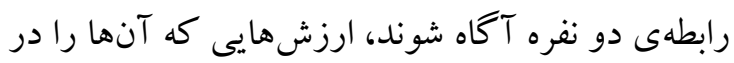

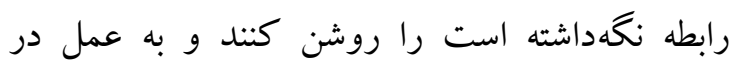
روشهايى كه به طور مداوم متناسب با اين اهداف هستند حتى در حضور افكار و احساسات ناخواسته متعهد شوند (امانالهى و همكاران، سهبا). معمولأ زوجها از موقعيتهاى مرتبط با آسيب، طرد و تعارض اجتناب مى كنند. درمان مبتنى بر يذيرش و تعهد به

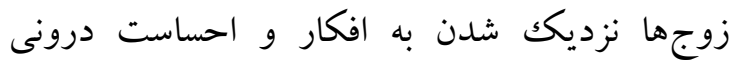
ناخواسته و حالات جسمانى مرتبط با اين بويايىها و الكوهاى ارتباط را آموزش مىدهد. به طور واضح نشان داده مىشود كه وقتى يكى از زوجها ازلحاظ عاطفى و

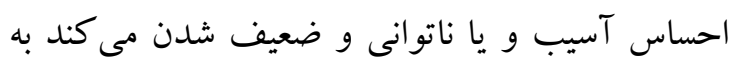
فاصلهى عاطفى روى مى آورد هرجند فاصلهى عاطفى

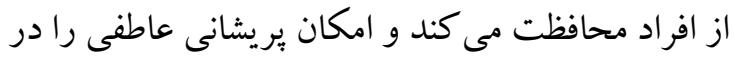
آينده كاهش مىدهد. با ياد گيرى و مهار اين افكار،

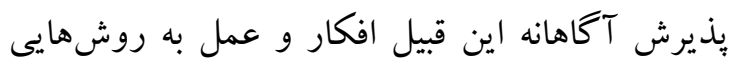
كه به طور مداوم ارتباط و صميميت عاطفى زوجها را هدف قرار مىدهد تمرين مىشود. همانطور كه زوج-

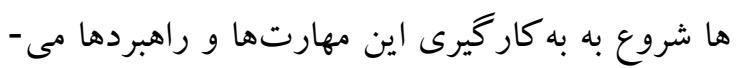
كنند بيشتر تمايل بيدا مى كنند و قادر مىشوند به به به موقعيتهاى اجتناب قبلى نزديكك شوند، به آنها فرصت رفتار به شيوهاى كه رضايت از رابطه را بهبود 
با توجه به ئزوهش (امان الهى و همكاران، سوسا)

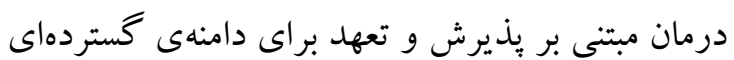
از مشكلات و مراجعان مؤثر است، اقتباس از درمان مبتنى بر بذيرش و تعهد در درمان بريشانى زوجها مى - مانى

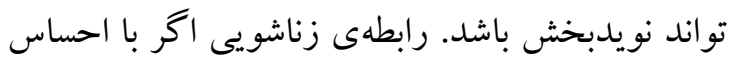
رضايت همراه باشد تأثير خوبى بر سلامت روان زوجين دارد. مىتوان كفت كيفيت رابطه زناشويى و ابعاد مختلف آن يكى از مهمترين عوامل پايدارى زندگى

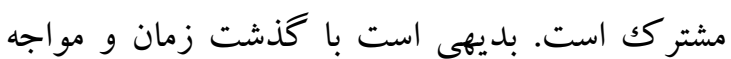
شدن با جالشهاى مختلف زندكى زناشويى از ميزان احساست مثبت دوران اوليه رابطه كاسته مىشود و مهمتر آنكه ممكن است زوجين مهارتهاى لازم براى بهبود كيفيت رابطه زناشويى نداشته باشند؛ بنابراين اين امر مىتواند با استفاده از مشاورهى زناشويى و و

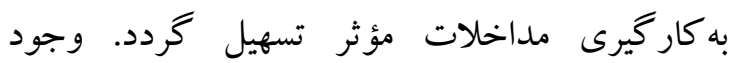
مشكلات رفتارى و ارتباطى در زندگىى، تأثير نامطلوب اين مشكلات در زندگى زوجها و فرزندان، ضرورت شناخت و يافتن راهحلهاى مؤثر در كاهش تعارضات و بهبود ارتباطات نامناسب زوجها از دلايلى هست كه اهميت اين بثزوهش را نشان مىدهد. لذا اين تحقيق هم از جنبهى نظرى و هم از جنبهى كاربردى داراى اهميت است. از لحاظ نظرى بيزوهش حاضر به افزايش دانش ما

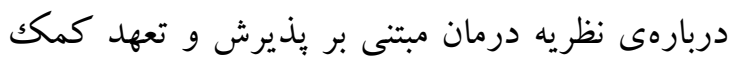

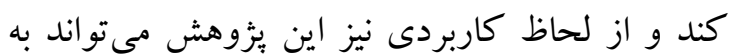

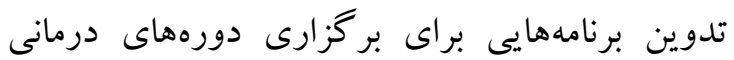

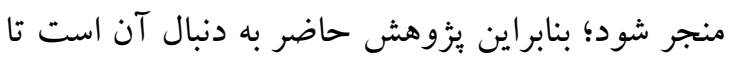
نشان دهد كه آيا شيوه درمان مبتنى بر يذيرش و تعهد بر آشفتحى زناشويى، تعارض زناشويى و خوشيينى در

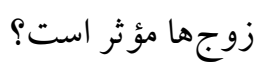

\section{روش يزوهش، جامعه آمارى و نمونه:}

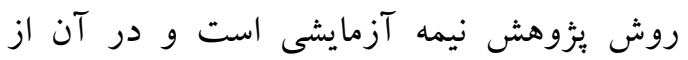

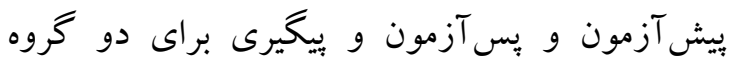

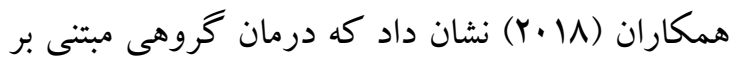

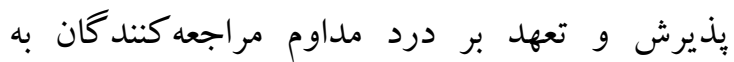
كلينيككهاى مراقبت اوليه مؤثر است. همجنين نتايج يُزوهش براسينگتون، فرى يا، ياتس، فرن، لانزا، كمبِ و

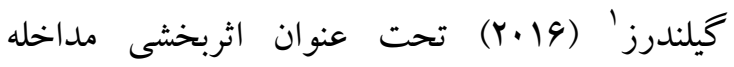
كروهى يذيرش و تعهد درمانى بر افراد با بيمارى

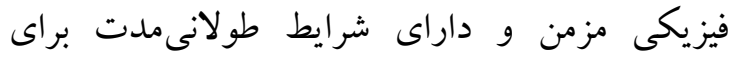

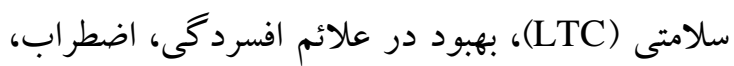
محدوديتهاى وضعيت سلامت و زندكى ارزشمند را

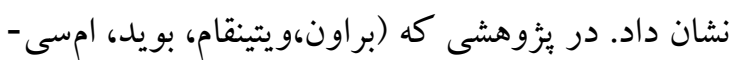
كين لاى و سوفرونف؛ اثربخشى درمان مبتنى بر بِذيرش و تعهد در بهبود

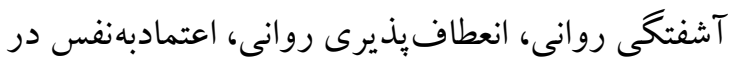
مديريت رفتار و اختلافات در زوجين داراى كود كان

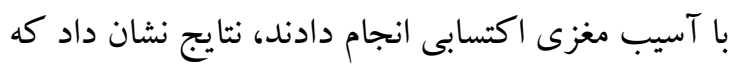
درمان مبتنى بر بذيرش و تعهد مؤثر بوده و اثرات بهبودى آن تا 9 ماه باقى ماند. هم جنين براج، كانكر و و

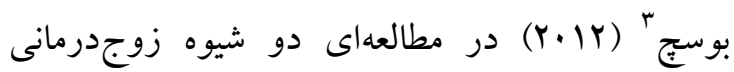
سيستمى و درمان مبتنى بر بذيرش و تعهد را بر روى

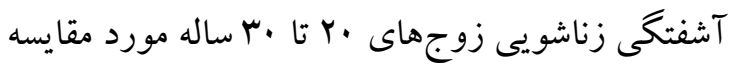

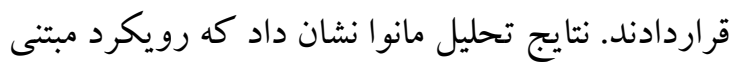
بر يذيرش و تعهد تمام متغيرهاى ارتباطى را بيش از زوجدرمانى سيستمى بهبود بخشيده است. نتايج مطالعه

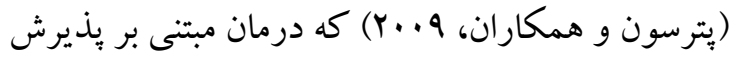
و تعهد را در درمان زوجهاى :ريشان بكار بردند، حاكى از آن بود كه هر دو زوج پِ از از بايان درمان ساز گارى خوب و مداومت در بهبود را نشان دادند. همجنين در مطالعه آنها بريشانى بين فردى كاهش يافت و زوجين تا بايان درمان به بهبودى ادامه دادند.

1 .Brassington, Ferreira, Yates, Fearn, Lanza, Kemp, \& Gillanders

2. Brown, Whittingham, Boyd, McKinlay, \& Sofronoff 3. Baruch, Kanker, \& Busch 
بررسى بيامدهاى رفتار مقابلهاى كذشته و به كارگيرى

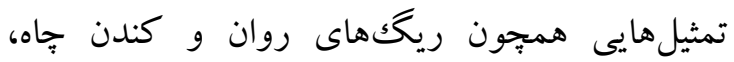
تمر كز روى ارزشها، شناسايى موانع عمل ارزشمند و ايفاى نقش بر اساس تمرين هيولاها در اتوبوس، تمركز روى گسلش شناختى و تمثيلهاى آن و در جلسات

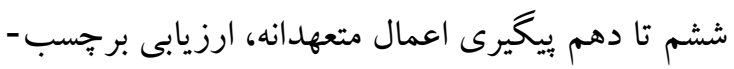

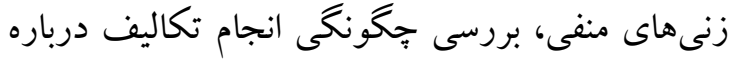

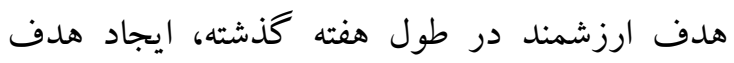
جديد براى هفته بيشرو و تمركز بر خشم بهعنوان يكك هن

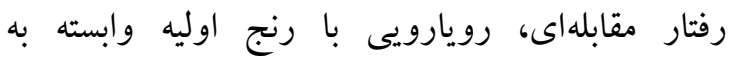
طرحوارهها، تصويرسازى ذهنى و تمرينهاى عملى با تمركز بر رهاسازى از راهبردهاى قديمى كنترل

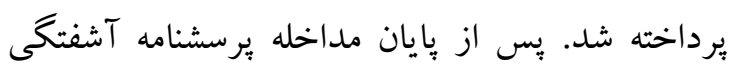
زناشويى، تعارض زناشويى و جهت گيرى به زندگى بهى براى بِ آزمون بر روى دو گروه آزمايش و گتواه بعد از آخرين جلسه درمان اجرا شد. همجنين به دليل رعايت ملاحظات اخلاقى جلسههاى فوقالذكر براى

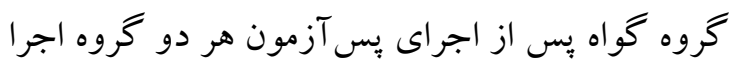

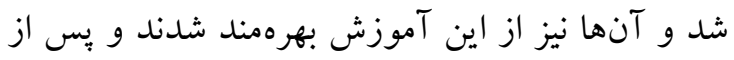

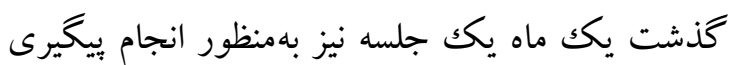

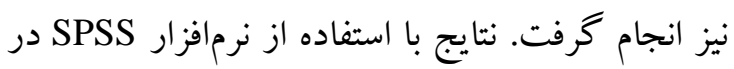

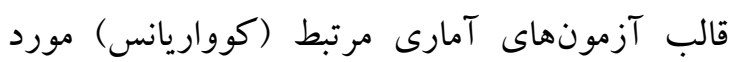
تجزيه و تحليل قرار كرفت.

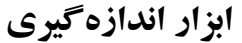

يرسشنامه آشفتكى زناشويى' (MSI-R): در اين إني

يثزوهش، ميزان آشفتخىزناشويى به وسيله فرم بازبينى شده يرسشنامه نارضايتى زناشويى اشنايدر

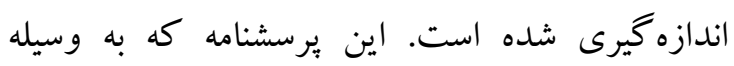

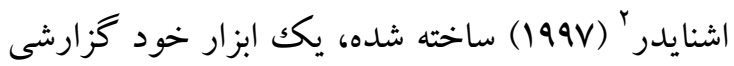
ا سؤالى است كه براى شناسايى ماهيت و ميزان.

1. Marital Satisfaction Inventory Revised 2. Snaydr
شامل گرووه آزمايش و كنترل استفادهده است و مرحله يِگيرى بس از يكك ماه اجراشده است. جامعه آمارى ئزوهش حاضر شامل كليه زنان متأهل شهر كرمانشاه كه در بهار سال 99 به خاطر مشكلات زناشويى به مركز مشاورهى كميته امداد مراجعه كرده-

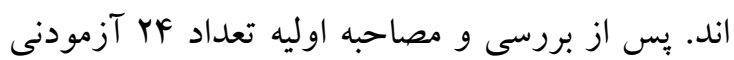
به صورت تصادفى بر اساس ملاككهاى ورود داشتن اختلاف زناشويى، زن بودن، متأهل بودن، ساكن شهر كرمانشاه بودن و داشتن حداقل تحصيلات خواندن و نوشتن و ملاككهاى خروج تحت درمانهاى روان-

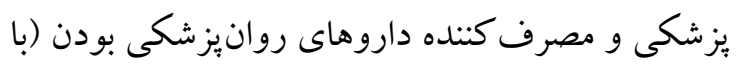

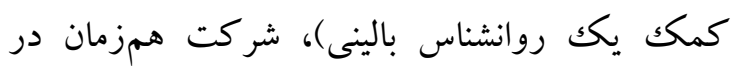
جلسات مشاوره و رواندرمانى و روانيزشكى، غيبت بهن در جلسات، عدم انجام تكاليف و ابراز عدم تمايل به ادامه همكارى و بر اساس استانداردهاى مشاورهى گروهى (نوابىنزاد، الهr|) در دو گروه آزمايش (r)

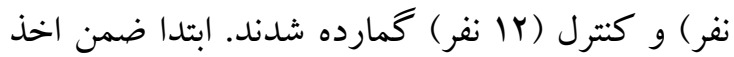
مجوزهاى لازم براى اجراى يثوهش از كميته امداد

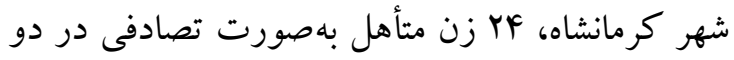

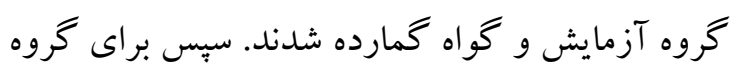
آزمايش جلسه درمان مبتنى بر يذيرش تعهد در قالب

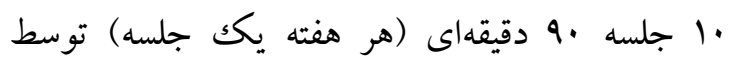
كارشناس ارشد مشاوره آموزشديده بركزار شد. در لر هر جلسه اول ابتدا اعضاء با يكديخر آشنا شدند و قوانين كروه ازجمله اهميت رازدارى و نظم در آمدن ... بيان

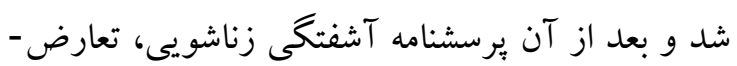

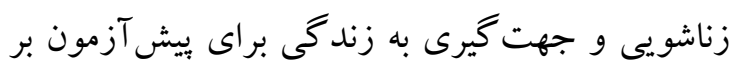

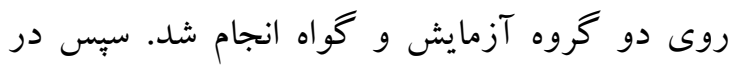

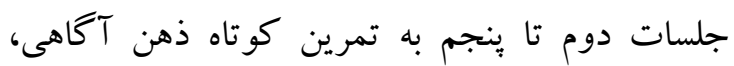
آموزش روانى ده طرحواره و رفتارهاى مقابلهاى ناشى بـ بـ

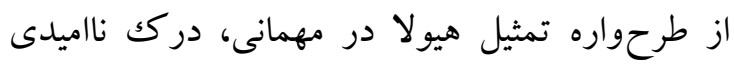
سازنده، بررسى نمونههايى از رفتارهاى مقابلهاى، 
نتايج مربوط به اعتبار آزمون مجدد اين برسشنامه كه به

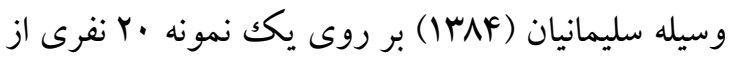
جامعه آمارى اجرا شد، داراى دامنه بين |ه/• ات 9 1/. و ميانگين VA/· است. روايى سازه برسشنامه با استفاده از تحليل عاملى و روايى محتوايى آن به وسيله ينج تن

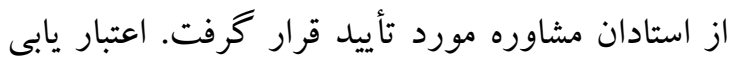
مجدد برسشنامه روى نمونه • • نفرى از جامعه آمارى،

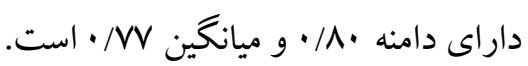

\section{يوسشناملى تعارض زناشويى (فرم تجديدنظر}

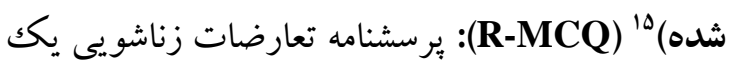
ابزار هF سؤالى است كه براى سنجيدن تعارضات زن و شوهرى توسط ثنايى و براتى و بوستانىيور (IrAV)

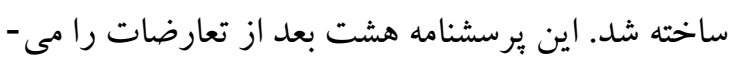
سنجد كه عبارتاند: كاهش همكارى، كاهش رابطهى جنسى، افزايش واكنشهاى هيجانى، افزايش جلب حمايت از فرزندان، افزايش رابطهى فردى با

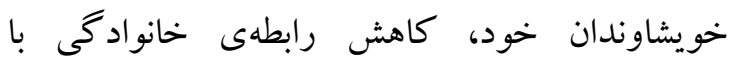
خويشاوندان همسر و دوستان، جدا كردن امور مالى از يكديخر و كاهش ارتباط مؤثر.

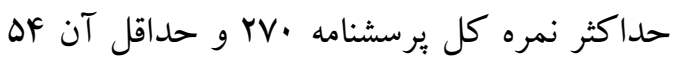
است. حداكثر نمره هر خرده مقياس مساوى با تعداد سؤالهاى آن خرده مقياسها ضربدر ها است. در اين ابزار نمره بيشتر به معنى تعارض بيشتر و نمره كمتر به

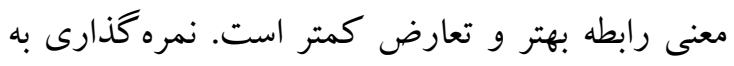

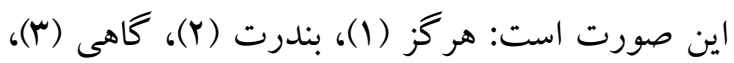

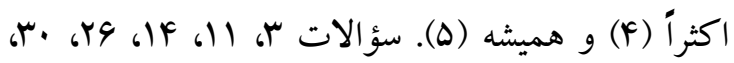

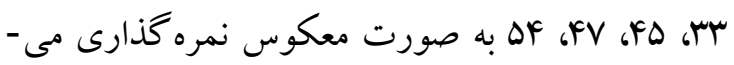

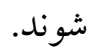
آلفاى كرونباخ براى كل برسشنامه در بزوهش ثنايى

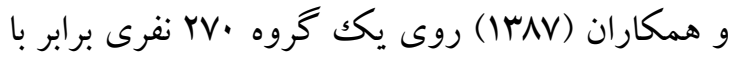

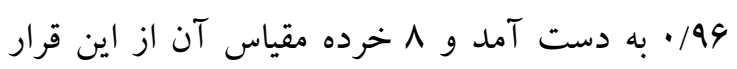

15. Marital Conflict Questionnaire
آشفتگى (نارضايتى) در روابط زناشويى مورد استفاده

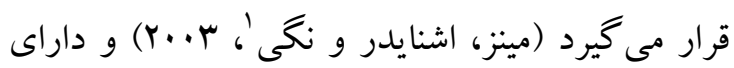
دو خرده مقياس روايى عدم ثبات و يايدارى آزمودنى

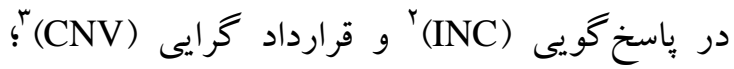

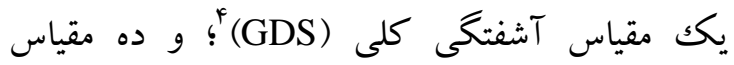
سنجش آشفتكى در ابعاد مختلف روابط زناشويى شامل ارتباط عاطفى (AFC)؛؛ توانيى حل مشكل (PSC) (TTO) '(SEX)

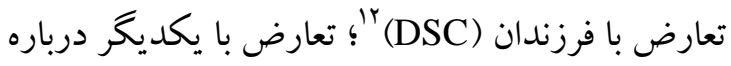
تربيت فرزند (CCR) است. سؤالها به صورت صفر و يكك نمره كذارى شده است و نمرههاى مربوط به هر خرده مقياس باهم جمع

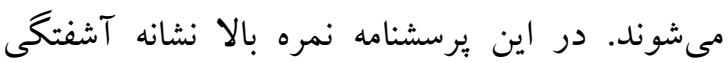
بيشتر و نمره كمتر نشانه رضايت بيشتر يا آشفتكى كمتر

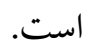
اشنايدر دو نوع اعتبار شامل ثبات درونى و آزمون

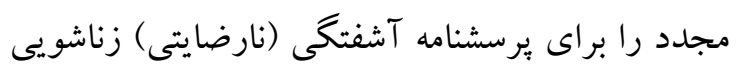
بيان كرده كه نتايج اعتبار ثبات درونى برحسب آلفاى - برسي

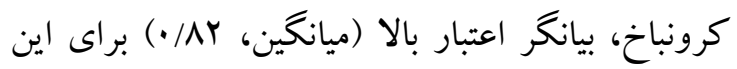

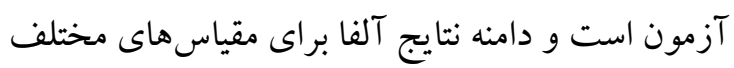
نيز از سو/· تا •V/ • بوده است. وى همِّنين ينج نوع

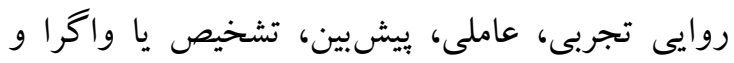

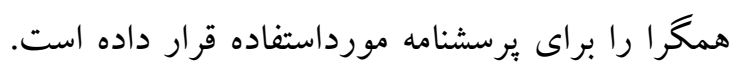

1. Means, Snyder, \& Negy

2. Inconsistency

3. Conventionalization

4. Global Distress

5. Affective Communication

6. Problem-Solving Communication

7. Aggression

8. Time Together

9. Disagrement about Finances

10. Sexual Dissatisfaction

11. Family History of Distress

12. Dissatisfaction with Children

13. Conflict Over Child Rearing

14. Role Orientation 
اين برسشنامه است. همجنين تحليل عاملى خوشيينى و

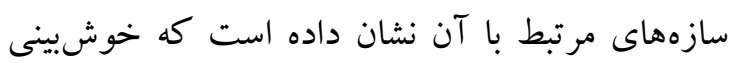

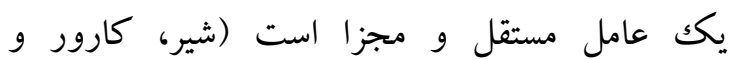

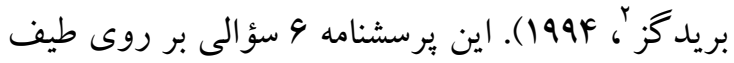

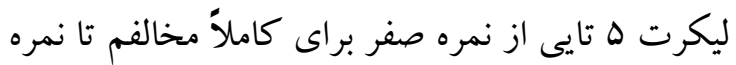

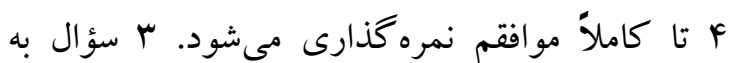
صورت معكوس نمره گذارى مىشود و كمترين نمره ممكن صفر و بالاترين FF است. ويزگىهاى روانسنجى اين برسشنامه در ايران توسط خدابخشى (rیr|) بررسى شده است و با نمره

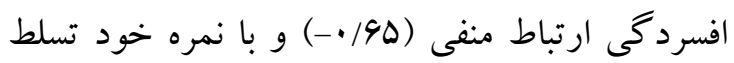

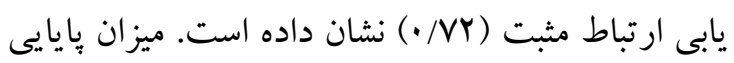

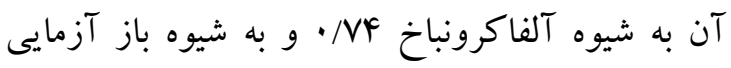

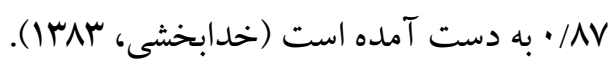
برنامه مداخله: جلسههاى درمان گروهى مبتنى بر يذيرش و تعهد بر اساس ساختار موجود در كتاب

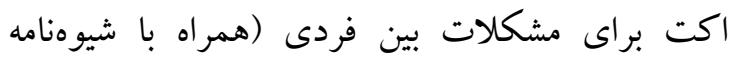

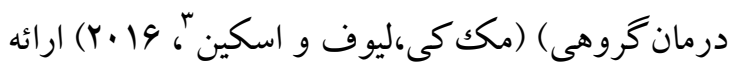
ارائه شده است.

2. Scheier, Carver \& Bridges 3. Mckay, Lev \& Skeen
است: كاهش همكارى، |N/ •؛؛ كاهش رابطهى جنسى،

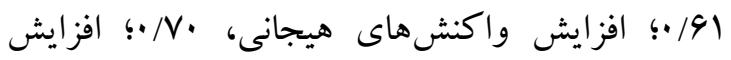
جلب حمايت فرزندان، سٓ/•؛ افزايش رابطهى فردى با خويشاوندان خود، 91/·؛ كاهش رابطهى خانوادكى با خويشاوندان همسر و دوستان، 9 ه/·؛ جدا كردن امور

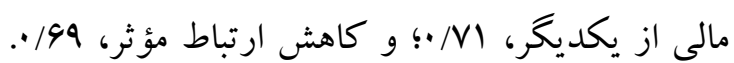
همجنين اين برسشنامه از روايى خوبى برخوردار است. در مرحلهى تحليل محتواى آزمون، پِس از اجراى

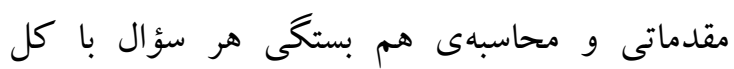

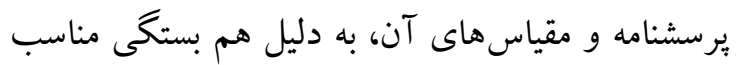
سؤالات، هيج سؤالى حذف نشد (ثنايى و همكاران IrAV با همسرم، رابطهى من با خانوادهى بدر و مادر او قطع مىشود) و (امن و همسرم حسابهاى مالى جداكانه داريم". همسانى (به روش آكلفاى كرونباخ) براى كل هل مقياس هاى اين برسشنامه برابر با •9/، به دست آمد و و براى ^ خرده مقياس به صورت زير بوده است:

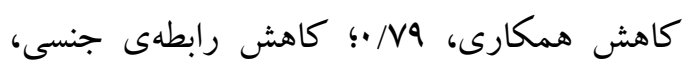

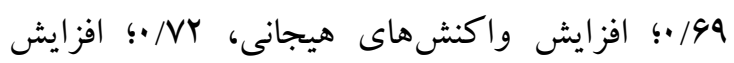
جلب حمايت فرزندان، وه/•؛ افزايش رابطهى فردى با خويشاوندان خود، /VA •• كاهش رابطهى خانوادكى با خويشاوندان همسر و دوستان، ·A/·؛؛ جدا كردن امور

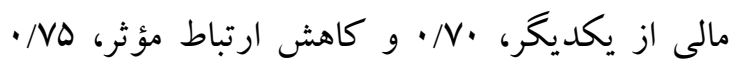
(ثنايى و همكاران، (INAV)

يرسشنامه جهت كيرى به زندكى' (LOT-R): اين يرسشنامه توسط (شير و كارور، له191) ساخته شده و

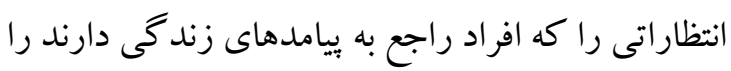

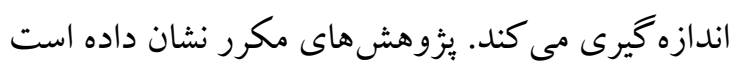
كه نمرات اين بيرسشنامه با طيف گستردهاى از سازههاى مرتبط مانند عزتنفس، ناميدى و روان آزرده

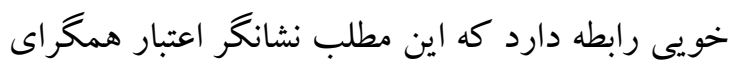

1. Revised Life Orientation Test 


\begin{tabular}{|c|c|}
\hline عنوان & جلسه \\
\hline 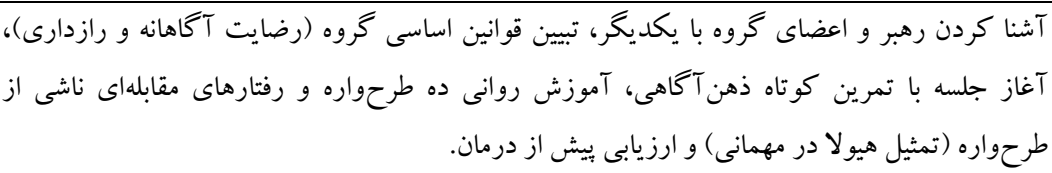 & اول \\
\hline برونه كلى ايى از رفتارهاى مقابلهاى. جلسه اول و ارائه بازخورد، تمرين ذهن آكاهى، درك ناميدى سازنده، بررسى & دوم \\
\hline 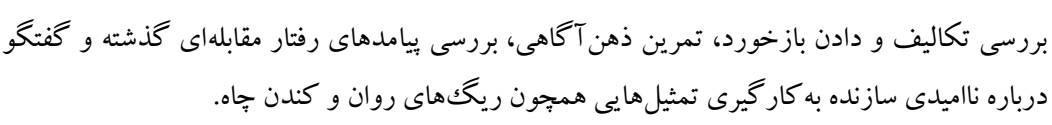 & سوم \\
\hline بررسى تكاليف و دادن بازخورد، تمرين ذهن آكاهى، تمركز روى ارزشها، شناسايى موانع عمل & جهارم \\
\hline تمركز روى كسلش تكاليف جلسه قبل و دادن بازخو رد، تمرين ذهن آكاهى بهمنظور ييوستگى در رشد اين مهارت، & ينجم \\
\hline براى منفى. تكاليف و دادن بازخورد، بيخيرى اعمال متعهدانه، تمر كز روى گسلش و ارزيابى برجسبزنى - & ششم \\
\hline 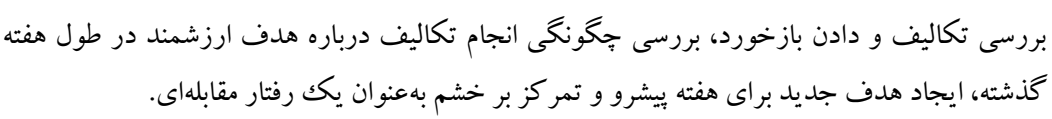 & هفتم \\
\hline رويارويى با رنج اوليه وابسته به طرحوارهها، تصويرسازى ذهنى و تمرينهاى عملى با تمر كز بر رهاسازى & هشتم \\
\hline بفازبينى بسيارى از موضوعات جديد و آموزش مهارتهار ارتباط. & نهم \\
\hline 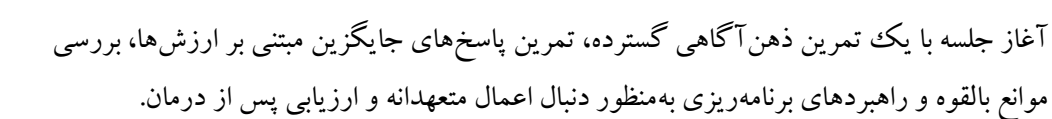 & دهم \\
\hline
\end{tabular}

آن تعداد، كمترين، بيشترين، ميانگين و انحراف معيار بهاعنوان آمارههاى توصيفى، استفاده شد. در راستاى تحليلهاى استباطى و و آزمون فرضيهاى تحقيق از روش تحليل آمارى اندازهيرى مكرر و تحليل كوواريانس استفاده شده است.

\section{شيوهى تجزيهوتحليل دادهها}

در اين مبحث با توجه به موضوع تحقيق حاضر كه دهون

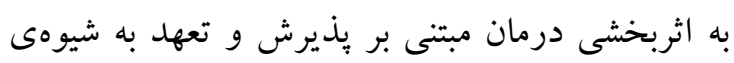

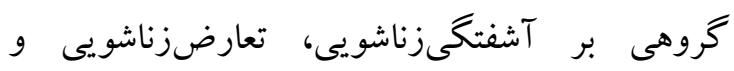
خوشبينى مى بردازد، در ابتدا بهمنظور توصيف آمارى،

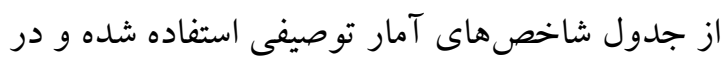




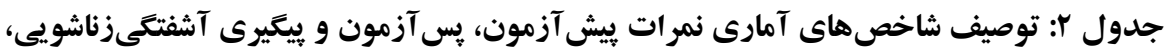

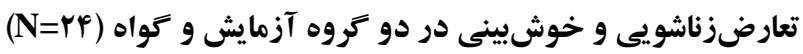

\begin{tabular}{cccc}
\hline شاخص هاى آمارى & & & \\
\hline
\end{tabular}

\begin{tabular}{|c|c|c|c|c|c|}
\hline$(11 / 19) 94 / 19$ & $(11 / 49) 90 / 99$ & $(V / \Delta I) V \Delta / r T$ & آزمايش & & آشفتخى \\
\hline$(\Delta / \Lambda \Lambda) \vee r / 94$ & $(r / \Delta q) V F / r r$ & $(r / 99) V F / Y D$ & كواه & نمره كل آشفتكى & زناشو يى \\
\hline$(\cdot / q \cdot) r / A V$ & $(\cdot / q \cdot) F / r)$ & $(\cdot / N) \Delta / \cdot \cdot$ & آزمايش & قرارداد گرايى & \\
\hline$(\cdot / \Lambda F) F / Q V$ & $(\cdot / N) \Delta / \cdot \cdot$ & $(\cdot / v \cdot) F / 91$ & كواه & & \\
\hline$(1 / Y \wedge) \Delta / F I$ & (I/ & $(1 / . r) 9 / A r$ & آزمايش & ارتباط عاطفى & \\
\hline$(1 / T V) V / F Y$ & $(1 / Y F) V / F I$ & 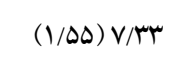 & كواه & & \\
\hline$(\cdot / A F) G / N$ & $(\cdot / \Lambda \Gamma) 4 / \Lambda \Gamma$ & $(1 / 19) \wedge / \Delta$. & آزمايش & حل مسئله & \\
\hline$(1 / N I) \wedge / \Delta F$ & (I/NI) $\Delta \Lambda / \Lambda$ & $(1 / r \Delta) \wedge / v \Delta$ & كواه & & \\
\hline$(1 / A V)) 1 / \cdot F$ & $(1 / 9 \Delta) 11 / \cdot \wedge$ & $(r / l \cdot) \mid r / \Delta \Lambda$ & آزمايش & آشفتگى كلى & \\
\hline$(1 / T \wedge) \mid r / Y q$ & $(1 / F q) \mid r / r r r$ & $(1 / F F) \mid r / \Delta$. & كواه & & \\
\hline$(\cdot / A Y) F / Y V$ & $(\cdot / 9 \mathrm{~V}) \mathrm{f} / \Delta$. & $(\cdot / \wedge \Delta) 4 / \cdot \cdot$ & آزمايش & يرخاشگرى & \\
\hline$(\cdot / M) \Delta / q$ & $(\cdot / M) \Delta / 94$ & (•/ar) $\Delta / \wedge r$ & كواه & & \\
\hline$(\cdot / V q) r / \Delta \cdot$ & $(\cdot / \vee q) \Gamma / \Delta \Lambda$ & $(1 / Y \Lambda) \Delta / r \Delta$ & آزمايش & زمان باهم بودن & \\
\hline$(\cdot / 9 \Delta) \Delta / F V$ & $(\cdot / \Delta 1) \Delta / \Delta \Lambda$ & $(\cdot / 49) 0 / 94$ & كواه & & \\
\hline$(\cdot / V I) F / A K$ & $(\cdot / 99) 4 / 91$ & $(1 / \cdot \Lambda) \Delta / \Delta \Lambda$ & آزمايش & عدم توافق درباره & \\
\hline$(\cdot / W V) \Delta / r q$ & $(\cdot / 9 \mathrm{~V}) \Delta / \Delta$. & $(\cdot / \Delta 1) \Delta / \Delta q$ & كواه & مسائل مالى & \\
\hline$(\cdot / \Lambda 1) \Gamma / \Lambda 1$ & $(\cdot / V 9) r / 91$ & $(1 / T V) 4 / \cdot$. & آزمايش & عدم رضايت & \\
\hline$(\cdot / 9 \uparrow) \Delta / 9$. & $(1 / \cdot \Lambda) \Delta / \Delta \Lambda$ & $(1 / 19) \Delta / \Delta$ & كواه & جنسى & \\
\hline$(\cdot / \Delta Y) Y / \Delta$. & $(\cdot / 4 q) Y / 94$ & $(1 / F 1) F / \ldots$ & آزمايش & جهت گيرى نقش & \\
\hline$(\cdot / V \Psi) f / \cdot \cdot$ & $(\cdot / N 1) f / 19$ & $(\cdot / v q) F / \cdot 1$ & كواه & & \\
\hline$(\cdot / 9 \cdot) \mathrm{m} / . \cdot$ & $(\cdot / \Delta V) T / 19$ & $(1 / F \Lambda) \Delta / r \Delta$ & آزمايش & تاريخجه & \\
\hline \multirow[t]{2}{*}{$(\cdot / 99) F / 91$} & $\left(\cdot /{ }^{W}\right) \Delta / \cdot \cdot$ & $(\cdot / V 1) \Delta / 19$ & كواه & مشكلات & \\
\hline & & & & زناشويى & \\
\hline$(\cdot / M M) r / ৭ ৭$ & $(\cdot / \Lambda \Gamma) r / N \mu$ & $(1 / N I) F / V D$ & آزمايش & عدم رضايت از & \\
\hline$(1 / 9 \cdot) F / r \Delta$ & $(1 / \Delta \cdot) F / F 1$ & $(1 / \Lambda r) F / \Delta \Lambda$ & كواه & فرزندان & \\
\hline$(1 / \cdot \wedge) \Upsilon / q$. & $(\cdot / 99) 4 / \cdot 1$ & $(1 / \Delta \wedge) \Delta / 19$ & آزمايش & تعارض با يرورش & \\
\hline$(1 / V 9) F / 94$ & $(1 / V \cdot) \Delta / \cdot \cdot$ & $(1 / 9 V) \Delta / \cdot \wedge$ & كواه & كود كان & \\
\hline \multirow[t]{2}{*}{$(\mid q / F \Delta)|F| / F \mid$} & $(1 \Delta / F q) \mid F Y / Y \Delta$ & $(\mid N / \mu F) \mid 9 N / \Delta$. & آزمايش & نمره كل تعارض & تعارض \\
\hline & & & & زناشويى & زناشو يى \\
\hline$($ YYQ/VD) $1991 \cdot 1$ & $(Y \cdot / 9 Y) \mid 9 N / \cdot \Lambda$ & $(Y \cdot / \Delta V)|9 \Lambda / 9|$ & كواه & & \\
\hline$(1 / r q) F Y / Y V$ & (1/Kr) & $(Y / Y \cdot) F \Delta / 19$ & آزمايش & كاهش همكارى & \\
\hline
\end{tabular}




\begin{tabular}{|c|c|c|c|c|c|}
\hline$(r / I r) \varphi \Delta / r r$ & $(r / \cdot r) F \Delta / F$. & $(r / \cdot \Lambda) F \Delta / \Delta \Lambda$ & كواه & & \\
\hline$(Y / \cdot Y) M Y / \Delta$. & $(Y / 19) r / / \Delta \Lambda$ & $(r / 1 \Delta) r q / 41$ & آزمايش & كاهش رابطه & \\
\hline$(1 / 9 Y) r 9 / \Delta \Lambda$ & (1/9.) r9/VD & $(1 / 9 Y) r 9 / 91$ & كواه & جنسى & \\
\hline$r q / 11) \& 1 / \Delta$. & $(Y / 1 \cdot)+1 / 94$ & $(Y / Y F) F q / Y \Delta$ & آزمايش & افزايش واكنش & \\
\hline$(\mathrm{I} / \mathrm{VA}) \times \& / A \mathrm{~V}$ & $(I / V Q) \& V / \cdot \cdot$ & $(1 / F \Lambda) F V / r \Delta$ & كواه & هيجانى & \\
\hline$(F / \mu F) r V / V q$ & $(F / r V) r V / q 1$ & $(F / F V) F I / V \Delta$ & آزمايش & افزايش جلب & \\
\hline \multirow[t]{2}{*}{$(1 . / 1 Y) \& 9 / \mathrm{V}}$. & $(Y / Y Y) F F / Y$. & (r/Tr) $F F / \pi r$ & كواه & حمايت از & \\
\hline & & & & فرزندان & \\
\hline$(1 / \wedge \Delta) r Y / 19$ & 19/AV) rY/rT & 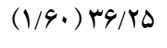 & آزمايش & افزايش رابطه & \\
\hline \multirow[t]{2}{*}{$(1 / A r) r G / F 1$} & $(1 / 9 F) r G / \Delta F$ & (1/91) r9/94 & كواه & فردى با & \\
\hline & & & & خو يشاوندان خود & \\
\hline$(Y / Q Y) Y \Delta / Y \Delta$ & $(Y / V I) Y \Delta / F 1$ & $(r / 9 \cdot) Y q / \cdot \Lambda$ & آزمايش & كاهش رابطه با & \\
\hline \multirow[t]{2}{*}{$(Y / 4 q) r \cdot / \cdot q$} & $(r / 91) r \cdot / r 1$ & $(r / 9 V) r \cdot / \pi$ & كواه & خو يشاوندان & \\
\hline & & & & همسر و دوستان & \\
\hline$(1 / \kappa \mu) \mu q / \mu F$ & $(1 / F F) F \cdot / F 1$ & $(1 / \Gamma 1)+1 / \cdot 1$ & آزمايش & جدا كردن امور & \\
\hline$(1 / V \Delta) r V / 9$. & $(1 / 91) r V / 94$ & $(1 / 91) r V / V q$ & كواه & مالى از يكديخر & \\
\hline$(1 / / F)$ HN/G. & $(1 / \Gamma \cdot)$ rN/99 & $(1 / q T) F F / \Delta$. & آزمايش & كاهش ارتباط & \\
\hline$(Y / A V) F F / Y$. & $(Y / A F) F F / Y G$ & $(r / \cdot r) F F / F 1$ & كواه & مؤثر & \\
\hline$(r / \Delta \Lambda) \mid \Delta / \wedge r$ & $(1 / \Delta F) 1 \Delta / \Delta$. & $(1 / N T) \mid r / \Delta$ & آزمايش & خوش & خوشبينى \\
\hline$(Y / \Delta \cdot) 11 / \cdot \Lambda$ & $(1 / \Delta 1) 11 / \Delta r$ & $(1 / \Gamma 1) 11 / \Delta$. & كواه & & \\
\hline
\end{tabular}

نتايج آزمون همسانى واريانس هاى لوين نشان داد كه

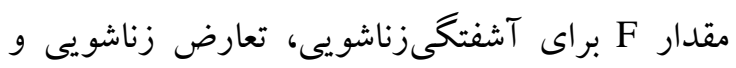

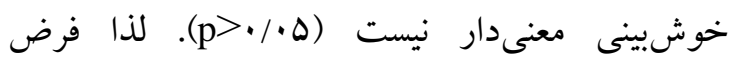
همسانى واريانس ها برقرار است. همجزين فرض بر ابرى

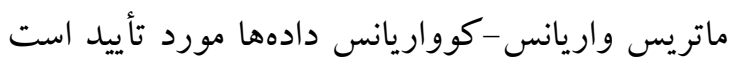
. $(\mathrm{p}>0.05)$
ميانخين و انحر اف استاندارد نمرات شر كت كنندهها در مر احل بيش آزمون، بس آزمون و ييخيرى در جدول

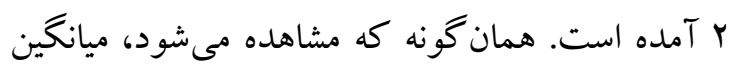
آشفتگى زناشويى و تعارضز اسناشويى و مؤلفهها يشان در

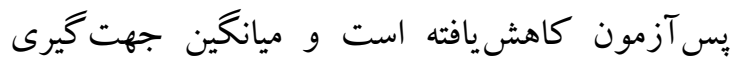
زندكى (خوشبينى) در پِ آزمون ارتقاء يافته است.

جدول rا: نتايج آزمون لامبداى ويلكس براى بررسى تأثيرات جند متغيره عامل دهاى درون كروهى و بين كروهى

\begin{tabular}{|c|c|c|c|c|c|c|c|c|}
\hline توان آمارى & مجذور اتا & $\mathbf{P}$ & خرآدى & فرادى & $\mathbf{F}$ & مقدار ويزه & منشأ تأثيرات & متغيرها \\
\hline$\cdot / \Delta r$ & .119 & .1 .4 & rr & 1 & $F / F A$ & $\Delta q \cdot / \mu q$ & بين گروهى & آشفتىى \\
\hline$\cdot / \Lambda$ & $\cdot / r F$ &.$/ .1$ & rl & $r$ & $\Delta / 9$. & .190 & درون گروهى & زناشويى \\
\hline$\cdot / N Y$ & $\cdot / r$. & $\%$ & rl & r & $4 / 99$ & .199 & تعامل & \\
\hline$\cdot 109$ & $\cdot / 1 \Lambda$ &.$/ \cdot r$ & rr & 1 & $F / A V$ & $\Delta 1 \wedge \Delta / \cdot 1$ & بين گروهى & تعارض \\
\hline $1 / \cdot$ & $\cdot / M \Lambda$ &..$/$. & r & r & $W / q$ &.$/ 11$ & درون گروهى & زناشويى \\
\hline
\end{tabular}




\begin{tabular}{|c|c|c|c|c|c|c|c|c|}
\hline $1 / \cdot$ & $\cdot / 1 \Lambda$ & $\cdot / \cdots$ & YI & r & $W / 9$ &.$/ 11$ & تعامل & \\
\hline$\cdot / 91$ & $\cdot / A V$ & $\cdot / \cdots$ & Yr & 1 & 19/9V & IM/AY & بين گروهى & خوشبينى \\
\hline$\cdot|A|$ & $\cdot / \mu \Delta$ & $1 \cdot 1$ & YI & r & $\Delta / V \Delta$ & .194 & درونگروهى & \\
\hline - $/ 19$ &.$/ 4$. & $\cdot / \cdot r$ & r) & r & V/Ir & .109 & تعامل & \\
\hline
\end{tabular}

درون گروهى با بين گروهى را نشان مىدهد از آنجا كه اثر تعاملى معنىدار است، لذا تحليل به تفكيك گرووهـا و با محوريت عامل تعاملى صورت مى يذيرد.
جدول r نتايج آزمون لامبداى ويلكس براى بررسى تأثيرات جندمتغيره عاملهاى درون خروهى و و بين گروهى و همسانى شيب رگرسيون در تعامل عامل

\begin{tabular}{|c|c|c|c|c|c|c|c|c|}
\hline توان & مجذور & معنى سطارى & خرجه & فرآدى & $\mathbf{F}$ & مقدار & منشأ تأثيرات & متغير ها \\
\hline .1 .9 & $\cdot 1.9$ & $\cdot / v$ & 1. & r &.$/ 49$ & . & كنترل & آشفتگى- \\
\hline$\cdot / v$ & $\cdot / \Delta 1$ & $\cdot / \cdot r$ & 1. & $r$ & $\Delta / r r$ & $\cdot / 4 \Lambda$ & گروه آزمايش & زناشويى \\
\hline$\cdot / \mathrm{VV}$ & .119 & $\cdot \mid * 1$ & 1. & $r$ &.$/ 90$ & $\cdot / \Lambda F$ & كنترل & تعارض- \\
\hline $1 / \cdot \cdot$ & . /af & $\cdot / \cdots$ & 1. & r & 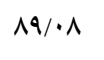 & .1 .0 & گروه آزمايش & زناشويى \\
\hline$\% \cdot v$ & /.r & $\cdot / N F$ & 1. & r & $\cdot / I V$ & $\cdot / 99$ & كنترل & خوش- \\
\hline$\cdot / A V$ &.$/ 91$ & $\cdot / \cdots 1$ & 1. & r & $N \cdot r$ & $\cdot / r \Lambda$ & گروه آزمايش & بينى \\
\hline
\end{tabular}

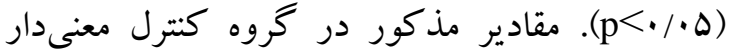

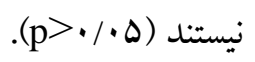

نتايج آزمون تحليل ماريانس در گروه آزمايش نشانداد (Greenhouse-Geisser) كه دامنه اندازهى اثر در نمره كل آشفتگى زناشويى بين

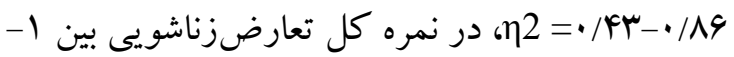
س

$$
\text { قراردارد. }
$$

جدول F نتايج آزمون لامبداى ويلكس براى

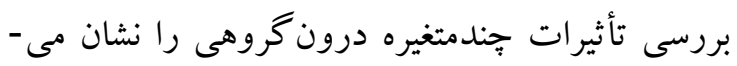
دهد. بر اين اساس سه مرحله بيش آزمون، بِ بس آزمون و

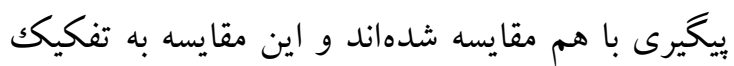

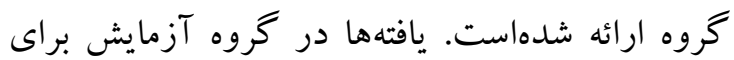
آشفتكىزناشويى • • براى تعارضزناشويى ا=لح، براى خوشبينى F بهدست آمد كه در گروه آزمايش معنى

\begin{tabular}{|c|c|c|c|c|}
\hline \multicolumn{2}{|c|}{ مقايسه سه مرحله } & مرحله (J) & مرحله (I) & متغير ها \\
\hline خطاى استاندارد & (I-J) تفاضل ميانكينها & & & \\
\hline$\cdot / r q$ & * & يس آزمون & ي يِش آزمون & ارتباط عاطف \\
\hline$\cdot / 49$ & $*_{1 / 4 r}$ & بيخيرى & بيش آزمون & \\
\hline
\end{tabular}

جدول ه: مقايسه خرده مقياسهاى آشفتكىزناشويى در سه مرحله تروه آزمايش 


\begin{tabular}{|c|c|c|c|c|}
\hline.$/ .4$ & .1 .9 & ي ييخيرى & مِس آزمون & \\
\hline$\cdot \pi$ & $* 1 / 9 \mathrm{~V}$ & 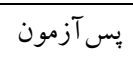 & ي بيش آزمون & حل مسئله \\
\hline • & $* 1 / \mathrm{W}$ & ييخيرى & ي يش آزمون & \\
\hline.$/ .1$ & $\cdot / 1$ & ي يخيرى & عِس آزمون & \\
\hline$\cdot / 11$ & $*_{1 / \Delta}$ & 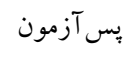 & بيش آزمون & يرخاشكرى \\
\hline.$/ . r$ & $* 1 / 94$ & 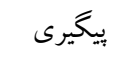 & يشي آزمون & \\
\hline .1 .0 & $\cdot / \mu$ & ييخيرى & مٍ آزمون & \\
\hline$\cdot / 49$ & $* 1 / 9 \mathrm{~V}$ & 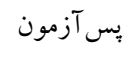 & ي يش آزمون & زمان با هم بودن \\
\hline$\cdot / 49$ & $*_{1 / N \Delta}$ & ي بيخيرى & ي بيش آزمون & \\
\hline$\cdot / .1$ & $\cdot / \cdot 1$ & بيخيرى & مٍ آزمون & \\
\hline$\cdot / 4 \wedge$ & $*_{Y / .9}$ & 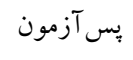 & ي يش آزمون & عدم رضايت جنسى \\
\hline$\cdot / 49$ & $*^{*} / 19$ & ييخيرى & بيش آزمون & \\
\hline.$/ 1$ & $\cdot / 1$ & بيخيرى & مِس آزمون & \\
\hline$\cdot / 94$ & $* 1 / \pi r$ & يس آزمون & يشي آزمون & جهت كيرى نقش \\
\hline$\cdot / \wedge 9$ & $*_{1 / \Delta}$ & بيخيرى & بيش آزمون & \\
\hline$\cdot / . r$ & $1 / 9$ & ييخيرى & عِس آزمون & \\
\hline$\cdot / 94$ & $*_{Y / / 9}$ & 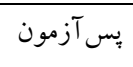 & ي بيش آزمون & ناريخجه مشكلات زناشويى \\
\hline$\cdot / M$ & *Y/YD & 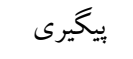 & بيش آزمون & \\
\hline. & $\cdot 119$ & بيغيرى & مجس آزمون & \\
\hline
\end{tabular}

معنىدار نشان مىدهد در نتيجه روش مداخله در اين

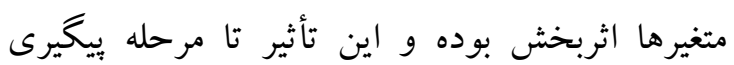
باقىماندهاست.
جدول ه مقايسه سه مرحله گروه آزمايش را در خرده مقياسهاى متغير آشفتخىزناشويى نشان مى مهد. خرده مقياس آشفتكىز زناشويى در مراحل بس بس آزمون و

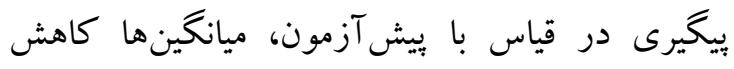

جدول \&: مقايسه خرده مقياسهاى تعارضزناشويى در سه مرحله كروه آزمايش

\begin{tabular}{|c|c|c|c|c|}
\hline \multicolumn{2}{|c|}{ مقايسه سه مرحله } & \multirow[t]{2}{*}{ مرحله (J) } & \multirow[t]{2}{*}{ مرحله (I) } & \multirow[t]{2}{*}{ متغيرها } \\
\hline خطاى استاندارد & تفاضل ميانكين ها (I-J) & & & \\
\hline.$/ .4$ & $* r / \wedge r$ & يس بـ آزمون & ي بيش آزمون & كاهش رابطهى جنسى \\
\hline 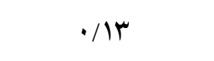 & $* \psi / q 1$ & ييخيرى & بيش آزمون & \\
\hline$\cdot / \mathrm{IV}$ & $\cdot / \cdot \Lambda$ & بيخيرى & ي بيش آزمون & \\
\hline$\cdot / F_{F}$ & $* \psi / \Delta q$ & يس آزمون & ي بيش آزمون & افزايش واكنش \\
\hline 每 & $* q / V \Delta$ & ييخيرى & ي بيش آزمون & 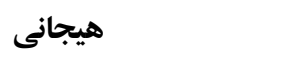 \\
\hline$\cdot / \cdot 1$ & .119 & بيخيرى & آزمون & \\
\hline .1 .4 & $*_{\Delta / \Lambda F}$ & يس آزمون & بيش آزمون & افزايش جلب حمايت \\
\hline$\cdot / \cdot r$ & $*_{r / 99}$ & ييخيرى & ي بيش آزمون & 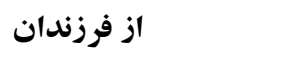 \\
\hline$\cdot / \cdot r$ &.$/ 10$ & بيخيرى & ي يس آزمون & \\
\hline
\end{tabular}




\begin{tabular}{|c|c|c|c|c|}
\hline$\cdot / T V$ & $* r / 9 r$ & يس آزمون & بيش آزمون & افزايش رابطه فردى با \\
\hline$\cdot / T \Delta$ & $* r / \cdot q$ & ي يِيرى & ي بيش آزمون & خويشاوندان خود \\
\hline$\cdot / \cdot r$ & $\cdot / I V$ & بيخيرى & يس آزمون & \\
\hline$\cdot / 11$ & $* r / 9 \mathrm{~V}$ & يس آزمون & ي يش آزمون & كاهش رابطه \\
\hline • & *r/Ar & يَيَيرى & ي بيش آزمون & خانوادكى با \\
\hline \multirow[t]{2}{*}{$\cdot / r \mid$} & $\cdot 119$ & بيخيرى & يֶ آزمون & خويشاوندان همسر و \\
\hline & & & & 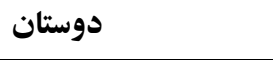 \\
\hline$\cdot / 94$ & $*_{\Delta / \Lambda F}$ & يس آزمون & ي بيش آزمون & كاهش ارتباط مؤثر \\
\hline$\cdot / \mathrm{Va}$ & $*_{\Delta / q}$ & ييخيرى & بيش آزمون & \\
\hline$\cdot 119$ & .1 .9 & بيخيرى & يس آزمون & \\
\hline
\end{tabular}

كاهش معنى دار نشان مى دهد درنتيجه روش مداخله در اين متغير اثربخش بوده و اين تأثير تا مرحله بيكيرى باقى مانده است.
جدول 4 مقايسه سه مرحله گروه آزمايش را در خرده مقياسهاى متغير تعارضززاشويى نشان مىدهد. خرده مقياسهاى تعارضزناشويى در مراحل يس آزمون و يِيَيرى در قياس با يِش آزمون، ميانگينها

جدول ץ: مقايسه خوشبينى در سه مرحله تروههاى آزمايش

\begin{tabular}{|c|c|c|c|c|}
\hline \multicolumn{2}{|c|}{ مقايسه سه مرحله } & مرحله (J) & مرحله (I) & متغير ها \\
\hline خطاى استاندارد & تفاضل ميانكينها (I-J) & & & \\
\hline$\cdot / 99$ & $* \mu / \cdots$ & بس آزمون & بيش آزمون & خوشبينى \\
\hline$\cdot / A r$ & $*^{*} / \Gamma r$ & يِيخيرى & ييش آزمون & \\
\hline$\cdot / \wedge \Delta$ & $\cdot / \mu F$ & بيخيرى & يس آزمون & \\
\hline
\end{tabular}

جدول V ل مقايسه سه مرحله گروه آزمايش را در ميانگينها افزايش معنىدار نشان مىدهد درنتيجه روش

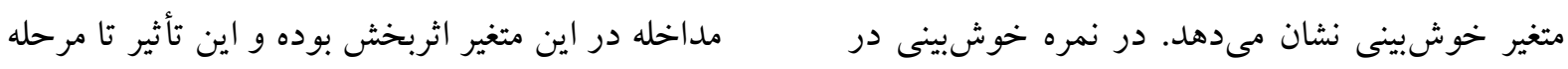

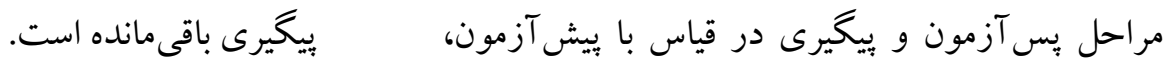

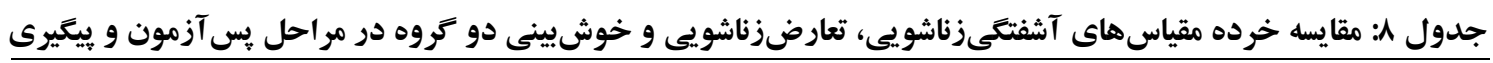

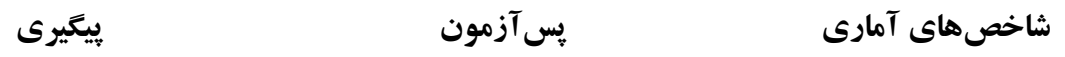

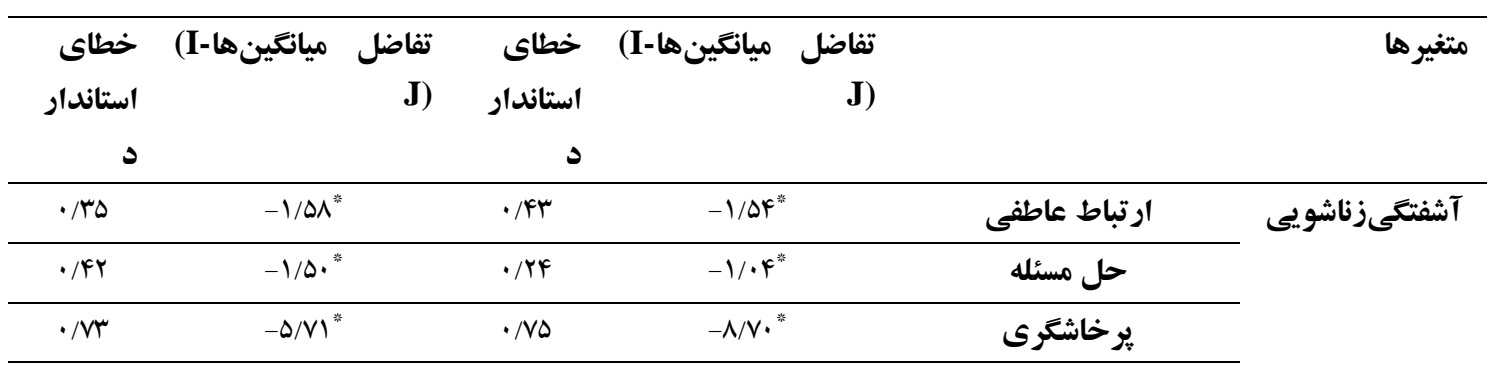




\begin{tabular}{|c|c|c|c|c|c|}
\hline$\cdot / \Delta V$ & $-r / \Delta \Lambda^{*}$ & $\cdot / \Delta \Lambda$ & $-\varphi / \cdot \wedge^{* *}$ & زمان با هم بودن & \\
\hline$\cdot / A r$ & $-4 / 9 \cdot *$ & $\cdot / \mathrm{AV}$ & $-9 / 0 \Lambda^{*}$ & عدم رضايتجنسى & \\
\hline$\cdot / \Delta$ & $-F / V Y^{*}$ & $\cdot / \Delta r$ & $-9 / V \Delta^{*}$ & جهت كيرى نقش & \\
\hline \multirow[t]{2}{*}{$\cdot / 9$} & $-V / 9 Y^{*}$ & .194 & $-9 / V r^{*}$ & تاريخجه مشكلات & \\
\hline & & & & زناشويى & \\
\hline$\cdot / 44$ & $-Y / 9 Y^{*}$ & $\cdot / \pi \Delta$ & $-r / I r^{*}$ & كاهش رابطهى جنسى & \multirow[t]{10}{*}{ تعارضز ناشويى } \\
\hline$\cdot / Y F$ & $-Y / 19^{*}$ & 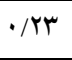 & $-1 / \Delta F^{* *}$ & افزايش واكنش هيجانى & \\
\hline$\cdot / 4$ & $-\varphi / \wedge r^{*}$ & $\cdot / 4 q$ & $-r / 9 I^{*}$ & افزايش جلب حمايت از & \\
\hline & & & & فرزندان & \\
\hline \multirow[t]{2}{*}{ • } & $-0 / 9 \cdot *$ & 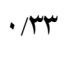 & $-9 / 9 Y^{* *}$ & افزايش رابطه فردى با & \\
\hline & & & & خويشاوندان خود & \\
\hline \multirow[t]{3}{*}{$\cdot / Y F$} & $-r / \wedge r^{* *}$ & . & $-r / F Q^{*}$ & كاهش رابطه خانوادكى & \\
\hline & & & & با خويشاوندان همسر و & \\
\hline & & & & دوستان & \\
\hline$\cdot / 14$ & $-1 / \cdots *$ & $\cdot / r V$ & $-1 / 2 \cdot *$ & كاهش ارتباط مؤثر & \\
\hline$\cdot / \cdot 1$ & $F / V Q^{*}$ & $\cdot / \cdot r$ & $r / 9 V^{*}$ & خوشينى & خوشبينى \\
\hline
\end{tabular}

حاصل از يزوهش در جدول (r و F) نشان داد كه درمان مبتنى بر بذيرش و تعهد تأثير معنادارى درو كاهش آشفتگىزناشويى و ت تعارضزناشويى دارد. همسو با اين إثوهش، يافتهاى امان الهى و همكاران

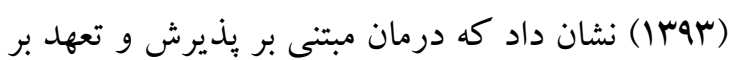

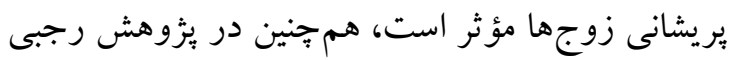

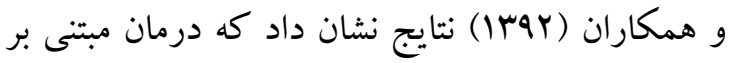
يذيرش و تعهد بر ساز كارى زناشويى زنان داراى

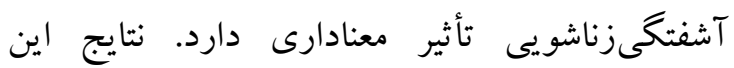
يثزوهش با يافتهاى قبلى (موسوى و همكاران، هوبا؛

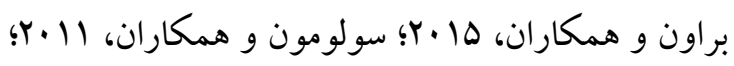

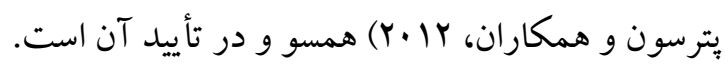
در تبيين يافتهاى اين يزوهش مىتوان علت اثربخشى درمان ACT ايجاد توافق و آموزش شيوههاى

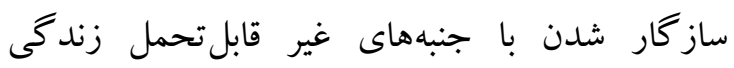
زناشويى به جاى تلاش براى مديريت آنها و عوامل

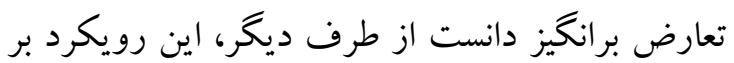

در جدول 1 مقايسه خرده مقياسهاى متغيرهاى آشفتكىزناشويى و تعارضزناشويى و متغير خوش بينى

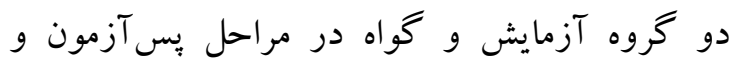
بيخيرى صورت گرفته است. نتايج نشان مىدهد كه

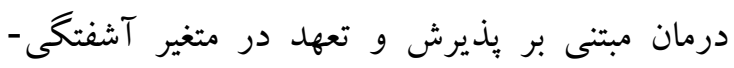

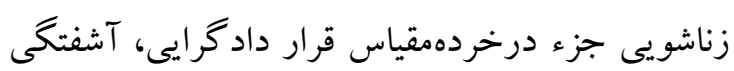
كلى، عدم توافق درباره مسائل مالى و عدم رضايت از فرزند و تعارض با برورش كودكان، متغير تعارض

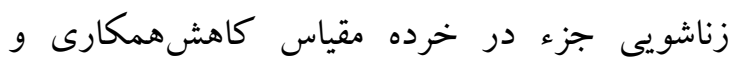
جداكردن امور ملى از يكديخر و در متغير خوشبينى درئ دردي در هر دو مرحله اثربخش بوده است، نتايج تا مرحله بيخيرى با ثبات بوده است.

\section{بحث و نتيجه كيرى}

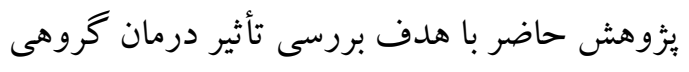

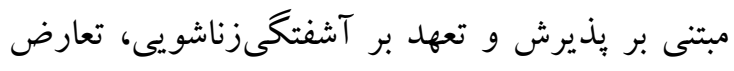
زناشويى و خوشبينى در زنان متأهل انجام شد. نتايج 
اجتناب و گام برداشتن در مسير زندگى مبنى بر ارزش ها براى تغيير رفتار است. هدف صريح در درمان ACT كاهش تلاش براى كنترلدرونى، اجتنابتجربهاى، افزايش كنترل رفتار و تمايل به تجربه كردن كستردهاى برى

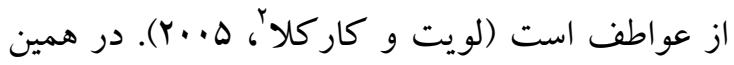

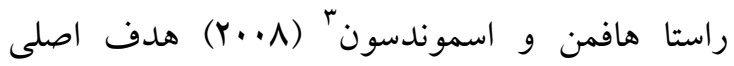
درمان ACT را درمان اجتنابهاى هيجانى، گسترش محتواى شناختى و ايجاد و حفظ تعهد در تغييرات

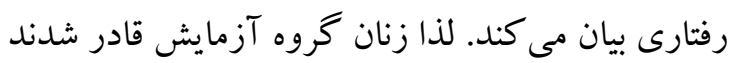
با تمرينهاى بذيرش و تمركز حواس حساسيتها و كنترلهاى خود را به مقدار قابلتوجهى كاهش دادئ داده و در نتيجه آشفتگى و تعارضزناشويى آنها به طور معنىدارى كاهش يافته است. يافتها در جدول (r و F) نشان داد كه درمان مبتنى بر بذيرش و تعهد تأثير معنادارى بر افزايش خوشبينى دارد. همسو با يافتهاى اين يثوهش، يافتهاى صادق

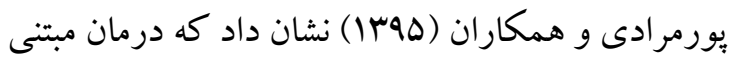
بر بذيرش و تعهد بر ميزان شادى و خوشبينى همسران

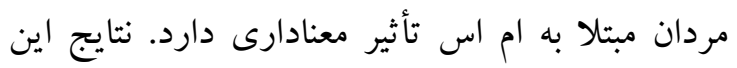
يزوهش يا يافتهاى تحقيقات قبلى (رجبى و همكاران،

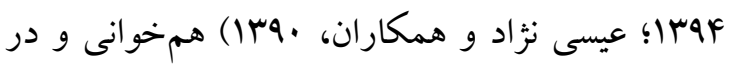
تأييد آن است.

همسو با نتايج يُزوهش، ياريس، دوناتو، پِاكانى و

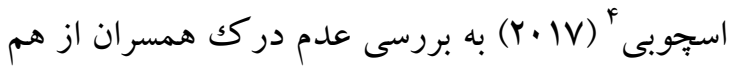
و اينكه آيا خوشبينى وياسخ هاى همسران را تعديل مى كند يا خير برداختند. اين بثزوهش را روى ب.ا زوج

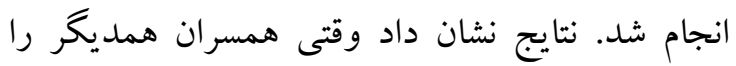
دركى نمى كنند رفتارهاى مثبت آنها كم و رفتارهاى منفى بيشتر مىشود و زوجينى كه خوشبين نيستند توانايى دركشان كم است. در همين راستا يُوهش

2. Levitt \& Karekla

3. Hofmann \& Asmundson

4. Parise, Donato, Pagani \& Schoebi

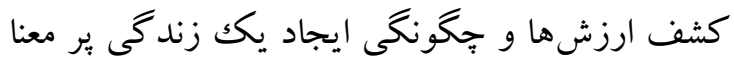
براى خود و همسر از طريق ايجاد ارزشهاى شخصى تأكيد مى كند و اين گونه زوجين تمام تجربههاى

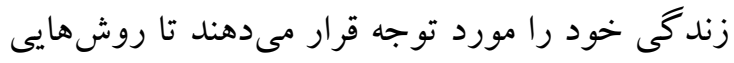
را براى زندگى كردن به شيوه كار آمدتر بيابند. درمان مبتى بر يذيرش و تعهد افراد را ترغيب مى كند كه

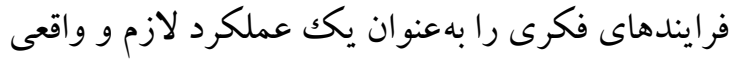
براى ساز گارى روانشناختى، بيذيرند و در درى نتيجه طرحوارههاى شناختى منفى را در افراد كاهش مىيابد. افر اد را قادر مىسازد تا به شيوه مؤثرترى شرايط سخت و بحرانى را مديريت كنند (لامار، ويترووسكى نهى

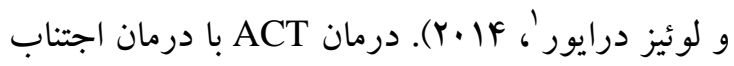
هيجانى، بهبود عكسالعملها، شناسايى ارزشها و و ايجاد تعهد نسبت به تغييرات رفتارى توانست به زنان متأهل كمكك كند تا رابطه زناشويى خود را بهبود

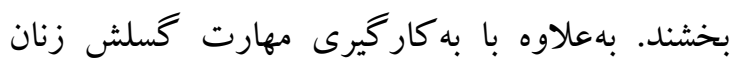

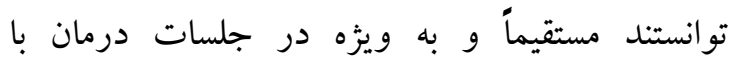
احساسات ناخوشايند سرو كار داشته باشند و به جاى كنترل كردن و به جالش كشيدن افكار و احساسات نامطلوب، آنها را تجربه كنند. در واقع اين درمان ياسخ هاى صميمانه و تبادل احساسات مثبت را در آنها افزايش داد. اين فرايند به آنها كمكك كرد تا به عميقترين تمايلات قلبى خود بى ببرند و اهميت رابطه زناشويى را در زندگى خود دريابند. در واقع بنا بر كزارش زنان مشاركت كننده در اين بيزوهش، برملا شدن ارزشها بهويزه ارزشهاى مشترك در رابطه زناشويى، تعارضات ميان آنها كاهش يافته و احساسات خوشايند و مثبت ترى را تجربه كردهاند.

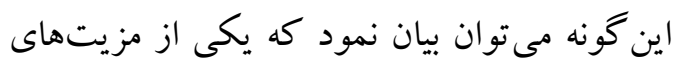

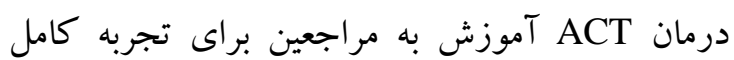
هيجانها و احساسهاى جسمانىشان بدون هيج گونه

1. Larmar, Wiatrowski \& Lewis-Driver 
آخرين بخش از نتايج بثزوهش نشان داد كه درمان

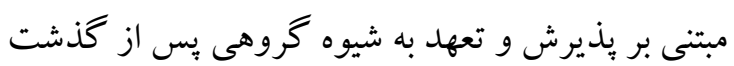
يكك ماه همجنان اثربخشى خود را حفظ كرده است؛ و

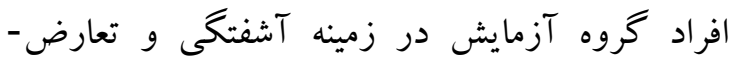
زناشويى و خوشبينى كارآمدتر از قبل از دوره و و

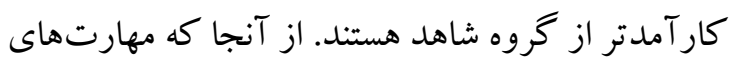
انتقال و تعميم و مهارتهاى نخهارى و تداوم آموزش

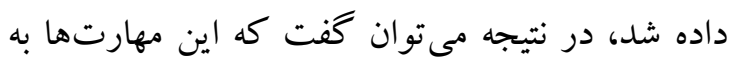
خوبى آموخته شده و و به كاربسته شدهاند. شر كت كنند گان از طريق به كار گرفتن اين مهارتها

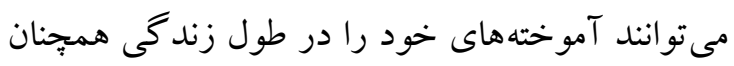
نكه داشته و مرور نمايند تا فراموش نكنند. اين عامل باعث مىشود تا اثربخشى دوره همرِنان در طول زمان باقى بماند. مهارتهاى نخهدارى و تداوم به افراد كمكك مى كند تا آنجه را كه در طول جلسات آموختهاند حفظ كرده، به كارگيرند و با استفاده از ازيه

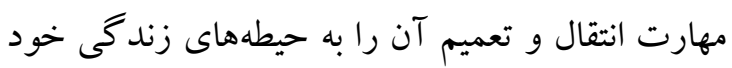
نيز گسترش دهند. حفظ و نخههارى مهارت و انتقال و تعميم آن به سايرحيطه ها نه تنها مانع فراموشى مهارتها

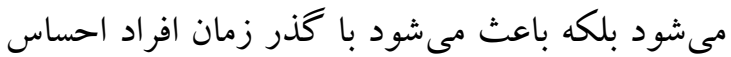
راحتى و ساز كارى بيشترى با محيط تجربه كنند.

\section{تشكر و قدردانى}

در پايان از اداره كميته امداد شهر كرمانشاه، كار كنان، مشاوران مركز مشاوره آواى مهر و تمامى افرادى كه به كهيته

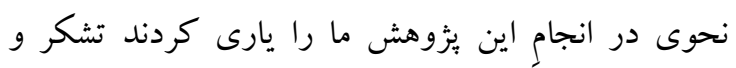
قدردانى مىشود.
جִֹگك، سدى كيدز و وايلد اسجات' (19 (Y) نشان داد كه ارتباطات اجتماعى و احترام به خود خوشبينى را افزايش مىدهد. در تبيين نتايج يثوهش مى توان كفت كه درمان

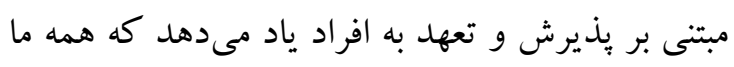
در زندكى رنج داريم، همهى افكار، احساسات، علائم

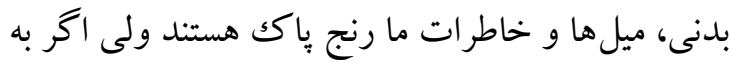
آنها زياد بها دهيم و يررنخشان كنيم باعث به وجود آمدن رنج ناياكك مىشود كه براى ما ناخوشايند خواهد بود، بنابراين با گسلش و نا هم آميزى شناختى مى توان

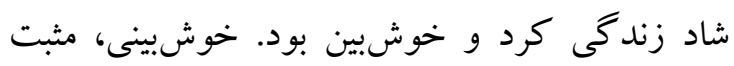
بودن سطحى نيست بلكه افراد خوشبين مشكل گشايند

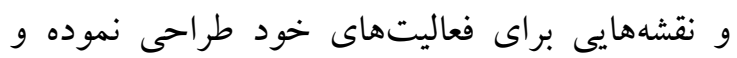

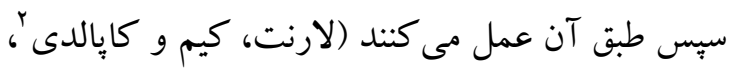

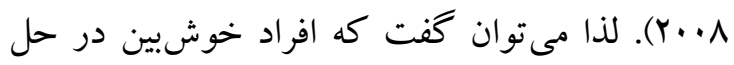
مسائل و مشكلات خود در زندكى زناشويى موفقتر

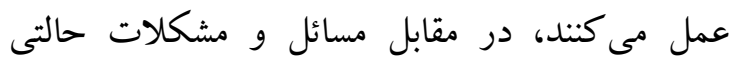

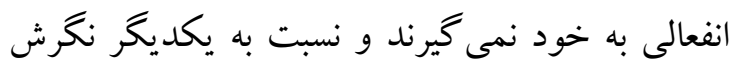

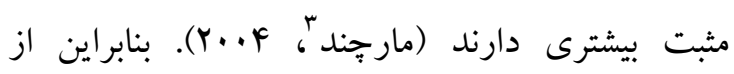
رضايت زناشويى بيشترى برخوردارند. يافتهاى اين يزٔوهش مى تواند اطلاعات مفيدى را براى مشاوران و و

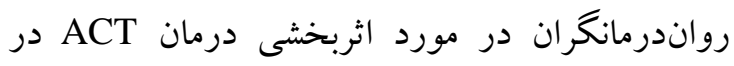
بهبود روابط زناشويى فراهم نمايد، همجنين اين

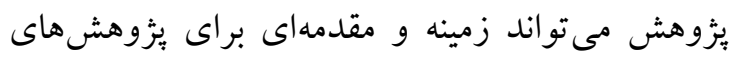

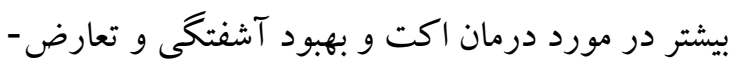
زناشويى و خوشبينى در روابط زوجين فراهم كند. در سالهاى اخير به دليل افزايش روزافزون آمار طلاق در

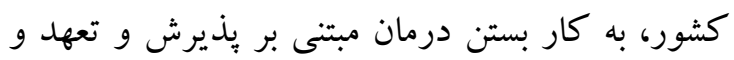

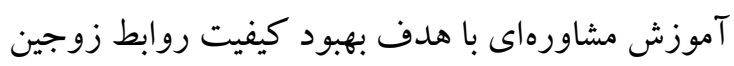
مى تواند به ثبات و يايدارى ازدواجها كمكك كند.

1. Cheung, Sedikides \& Wildschut

2. Laurnet, Kim \& Capaldi

3. Marchand 


\section{Reference}

Amanulahi, A., Heidarianfar, N., Khojestamehr, R., Imani, M. (2015). The effectiveness of acceptance and commitment (ACT) in the treatment of distress in couples. Journal of Applied Counseling, (1) 4, 103-119. [In Persian].

Assad, K. K., Donnellan, M. B., \& Conger, R. D. (2007). Optimism: An enduring resource for romantic relationships. Journal of Personality and Social Psychology, 93(2), 285-297.

Azimifar, Sh., Fatehizadeh, M., Bahrami, F., Ahmadi, S-A., Abedi, A. (2017). Comparing the effects of cognitive-behavioral couple therapy and acceptance and commitment therapy is marital happiness of dissatisfied couples.Shenakht Journal of Psychology and Psychiatry, (2) 3, 56-81. [In Persian].

Baruch, D., Kanker, J., \& Busch A. (2012). Acceptance and commitment therapy: Enhancing the relationships. Journal of Clinical Case Studies, 8(3), 241-257.

Brassington, L., Ferreira, N. B., Yates, S., Fearn, J., Lanza, P., Kemp, K., \& Gillanders, D. (2016). Better living with illness: A transdiagnostic acceptance and commitment therapy group intervention for chronic physical illness. Journal of Contextual Behavioral Science, 5(4), 208214.

Brown, F. L., Whittingham, K., Boyd, R. N., McKinlay, L., \& Sofronoff, K. (2015). Does stepping stones triple plus acceptance and commitment therapy improve parent, couple, and family adjustment following paediatric acquired brain injury? A randomised controlled trail. Behavior Research and Therapy, 73, 58-66.

Carver, C. S., Scheier, M. F., \& Segerstrom, S. C. (2010). Optimism. Clinical Psychology Review, 30(7), 879889.

Chalal Ghuchan Atiq, Y., Saraii, F. (2017). The effectiveness of acceptance and commitment therapy on marital satisfaction, sexual satisfaction, and satisfaction with women's lives.Journal of Mental Health, (Special Issue) 18, 529533. [In Persian].

Cheung, W.-Y., Sedikides, C., \& Wildschut, T. (2016). Induced nostalgia increases optimism (via socialconnectedness and self-esteem) among individuals high, but not low, in trait nostalgia. Personality and Individual Differences, 90, 283-288.

Coie, J. D., Watt, N. F., West, S. G., Hawkins, J. D., Asarnow, J. R., Markman, H. J., \& Long, B. (1993). The science of prevention: A conceptual framework and some directions for a national research program. American Psychologist, 48(10), 1013-1022.

Frankel, L. A., Umemura, T., Jacobvitz, D., \& Hazen, N. (2015). Marital conflict and parental responses to infant negative emotions: Relations with toddler emotional regulation. Infant Behavior and Development, 40, 73-83.

Fincham, F. D., \& Beach, S. R. (1999). Conflict in marriage: Implications for working with couples. Annual Review of Psychology, 50(1), 47-77.

Glasser, W. (2010). Choice theory: A new psychology of personal freedom: Harper Collins.

Glasser, W. (1998). Choice theory. A new psychology of personal freedom. New York Harper Collins Publisher.

Halford, W. K. (2001). Can skills training prevent relationship problems in at-risk couples? Four-year effects of a behavioral relationship education program. Journal of Family Psychology, 15(4), 750768.

Hammett, J. F., Castañeda, D. M., \& Ulloa, E. (2016). The association between affective and problem-solving communication and intimate partner violence among Caucasian and Mexican American couples: a dyadic approach. Journal of Family Violence, 31(2), 167178.

Hayes, S. C. (2016). Acceptance and Commitment Therapy, Relational Frame Theory, and the Third Wave of Behavioral 
and Cognitive Therapies-Republished Article. Behavior Therapy, 47(6), 869-885.

Hayes, S. C., Luoma, J. B., Bond, F. W., Masuda, A., \& Lillis, J. (2006). Acceptance and commitment therapy: Model, processes and outcomes. Behaviour Research and Therapy, 44(1), 1-25.

Hayes, S. C., Strosahl, K. D., \& Wilson, K. G. (2011). Acceptance and commitment therapy: The process and practice of mindful change. Guilford Press.

Hofmann, S. G., \& Asmundson, G. J. (2008). Acceptance and mindfulness-based therapy: New wave or old hat?. Clinical Psychology Review, 28(1), 1-16.

Hosseinian, S., Hosseini, F., Shafiyenia, A., Ghasemzadeh, s. (2009). Relationship between marital distress of mothers and the life of their marriad children. Journal of Women Studies, (6) 4, 81-103. [In Persian].

Isa-Nejad, O., Ahmadi; S-A., Bahrami, F., Baghban, I., Shoja Heidari, M. (2012). Effectiveness of relationship enhancement education on promoting optimism marital happiness. Journal of Psychological New Research, (21) 6, 129-149. [In Persian].

Johnson, S., \& Lebow, J. (2000). The "coming of age" of couple therapy: A decade review. Journal of Marital and Family Therapy, 26(1), 23-38.

Kamp Dush, C. M., \& Taylor, M. G. (2012). Trajectories of marital conflict across the life course: Predictors and interactions with marital happiness trajectories. Journal of Family Issues, 33(3), 341-368.

Kanzler, K. E., Robinson, P. J., McGeary, D. D., Mintz, J., Potter, J. S., Muñante, M., ... \& Velligan, D. I. (2018). Rationale and design of a pilot study examining Acceptance and Commitment Therapy for persistent pain in an integrated primary care clinic. Contemporary Clinical Trials, 66, 28-35.

Kavosyan, J., Harifi, H. Karami, K. (2017). The effectiveness of acceptance and commitment therapy On marital satisfaction of couples.Journal of Health And Care, (1) 19, 75-87. [In Persian].

Khoda- Bakhshi, M. (2005). Standardization, validity and reliability of the optimism scale in Isfahan, Thesis unpublished master of psychology, school of educational sciences and psychology, University of Isfahan. [In Persian].

Kreider, R. M., \& Fields, J. M. (2002). Number, timing, and duration of marriages and divorces, 1996. US Department of Commerce, Economics and Statistics Administration, US Census Bureau.

Laurent, H. K., Kim, H. K., \& Capaldi, D. M. (2008). Prospective effects of interparental conflict on child attachment security and the moderating role of parents' romantic attachment. Journal of Family Psychology, 22(3), 377-388.

Levitt, J. T., \& Karekla, M. (2005). Integrating acceptance and mindfulness with cognitive behavioral treatment for panic disorder. In Acceptance and mindfulness-based approaches to anxiety (pp. 165-188). Springer US.

Lyons, K. S., Stewart, B. J., Archbold, P. G., \& Carter, J. H. (2009). Optimism, pessimism, mutuality, and gender: Predicting 10-year role strain in Parkinson's disease spouses. The Gerontologist, 49(3), 378-387.

Marchand, J. F. (2004). Husbands' and wives' marital quality: The role of adult attachment orientations, depressive symptoms, and conflict resolution behaviors. Attachment \& Human Development, 6(1), 99-112.

Matthew, M., Avigail, L., Michelle, S. (2016). ACT for interpersonal problems using mindfulness, acceptance, and schema awareness to chang interpersonal behaviors (with method of letter group therapy). Translation by Mahmoud Roghanchi, Rezvan-Sa'adat Jazayeri, ozar Etemadi, Maryam Fatehizadeh, Khademorad Momeni and Seyed Mohsen Hojat Khah (2017). Kermanshah: University of razi. 
Means- Christensen, A. J., Snyder, D. K., \& Negy, C. (2003). Assessing nontraditional couples: validity of the marital satisfaction inventory- revised with gay, lesbian, and cohabiting heterosexual couples. Journal of Marital and Family Therapy, 29(1), 69-8.

Milligan, M. (2003). Optimismand fivefactor model of personality, Coping and health. Behavior. $\mathrm{PhD}$ dissertation psychology's Personality. Burn University.

Mincu, C. L., \& Taşcu, A. (2015). Social Support, Satisfaction with Physician-Patient Relationship, Couple Satisfaction, Body Satisfaction, Optimism as Predictors of Life Satisfaction in People having a Current Perceived Health Problem. Procedia-Social and Behavioral Sciences, 187, 772-776.

Mousavi, M., Rashidi, A., Golmohammadian, M. (2017). The effectiveness of acceptance and commitment therapy On increasing the marital satisfaction of veteran and free wives. Journal of Applied Counseling, (2) 5, 97-112. [In Persian].

Navabinejad, Sh. (2013). Group guidance and counseling. Tehran: Samt. [In Persian].

Oprisan, E., \& Cristea, D. (2012). A few variables of influence in the concept of marital satisfaction. Procedia-Social and Behavioral Sciences, 33, 468-472.

Parseh, M., Naderi, F., MehrbasiZadeh, M. (2016). The effectiveness of the cognitive-behavioral therapy family on conflict and satisfaction in couples visited the psychological centers. Journal of Clinical Psychology Achievments, (1) 1, 125-148. [In Persian].

Peterson, B. D., Eifert, G. H., Feingold, T., \& Davidson, S. (2009). Using Acceptance and Commitment Therapy to Treat Distressed Couples: A Case Study With Two Couples. Cognitive and Behavioral Practice, 16(4), 430-442.

Powdthavee, N., \& Vignoles, A. (2008). Mental health of parents and life satisfaction of children: A within-family analysis of intergenerational transmission of well-being. Social Indicators Research, 88(3), 397-422.

Rajabi, Gh., Imani, M., Khojestamehr, R., Biraami, M., Beshlide, K. (2014). Assessment of acceptance and commitment therapy in Couples Therapy Behavioral Integrated on Concern and marital adjustment of women with marital distress and general anxiety disorder. Journal of Behavioral Sciences Research, (6) 11, 600-619. [In Persian].

Rajabi, Gh., Jamali, A., Taghipour, M.(2016). The relationship between safe attachment style, self-differentiation (My Position) And marital satisfaction with the optimism of couples. Journal of Consuling Research, (14) 56, 46-67. [In Persian].

Rice, L. P. (1996). Intimate relationship marriage and family. California: Cole.

Roberts, L. J. (2000). Fire and ice in marital communication: Hostile and distancing behaviors as predictors of marital distress. Journal of Marriage and Family, 62(3), 693-70.

Sabatelli, R. M., \& Bartle- Haring, S. (2003). Family- of- Origin Experiences and Adjustment in Married Couples. Journal of Marriage and Family, 65(1), 159-169.

Sadeghpour-Moradi, Z., Nasirian, M., Chabokinejad, Z. (2017). The effectiveness of acceptance and commitment therapy ACT On the happiness and optimism of the wives of men with MS. First International Conference of New Research In the field of Educational Science and psychology and social studies of Iran, ghom,Conference Official Secretariat. [In Persian]

Sanaii, B. , Barati, T., Bostanipour, A. (2009). Scales of marriage and family assessment. Tehran: Besat. [In Persian].

Sayers, S. L., Kohn, C. S., Fresco, D. M., Bellack, A. S., \& Sarwer, D. B. (2001). Marital cognitions and depression in the context of marital discord. Cognitive Therapy and Research, 25(6), 713-732.

Scheier, M. F \& Carrer, C. S. (2001). Optimism, coping and health assessmental 
implication of generalized outcom expectancies. Health Psychology, 3 (1), 219-243.

Scheier, M. F., Carver, C. S., \& Bridges, M. W. (1994). Distinguishing optimism from neuroticism (and trait anxiety, self-mastery, and self-esteem): A reevaluation of the Life Orientation Test. Journal of Personality and Social Psychology, 67(6), 1063-1078.

Seligman, M. E . (2011). Learned optimism: How to change your mind and your life. Vintage.

Siffert, A., \& Schwarz, B. (2011). Spouses' demand and withdrawal during marital conflict in relation to their subjective well-being. Journal of Social and Personal Relationships, 28(2), 262277.

Snyder, D. K. (1997). Marital satisfaction inventory, revised (MSI-R). Los Angeles, CA: Western Psychological Services.

Soleimanian, A., Nawabi Nejad, Sh., Farzad, W. (2006). Determine the effectiveness of systematic motivational counseling group (SMC) on reducing marital distress. Journal of Consuling Research, (16) 4, 9-24. [In Persian].

Solomon, Z., Debby-Aharon, S., Zerach, G., \& Horesh, D. (2011). Marital adjustment, parental functioning, and emotional sharing in war veterans. Journal of Family Issues, 32(1), 127-147.

Van Epp, M. C., Futris, T. G., Van Epp, J. C., \& Campbell, K. (2008). Family and Consumer Sciences. Family and Consumer Sciences Research Journal, 36(4), 328349.

Weiss, R. L., \& Heyman, R. E . (1997). A clinical-research overview of couples interactions. In W. K. H. H. J. Markman (Ed.), Clinical handbook of marriage and couples interventions (pp. 13-41). Hoboken, NJ, US. John Wiley \& Sons Inc.

Whisman, M. A., Sheldon, C., \& Goering, P. (2000). Psychiatric disorders and dissatisfaction with social relationships: Does type of relationship matter. Journal of Abnormal Psychology, 109(4), 803-808.

Young, M. E., \& Long, L. L. (1998). Counseling and therapy for couples. Thomson Brooks/Cole Publishing Co. 